\title{
A review of micro-mechanical cutting
}

\section{Brian Boswell, M. N. Islam \& Ian J. Davies}

The International Journal of Advanced Manufacturing Technology ISSN 0268-3768

Int J Adv Manuf Technol DOI 10.1007/s00170-017-0912-y

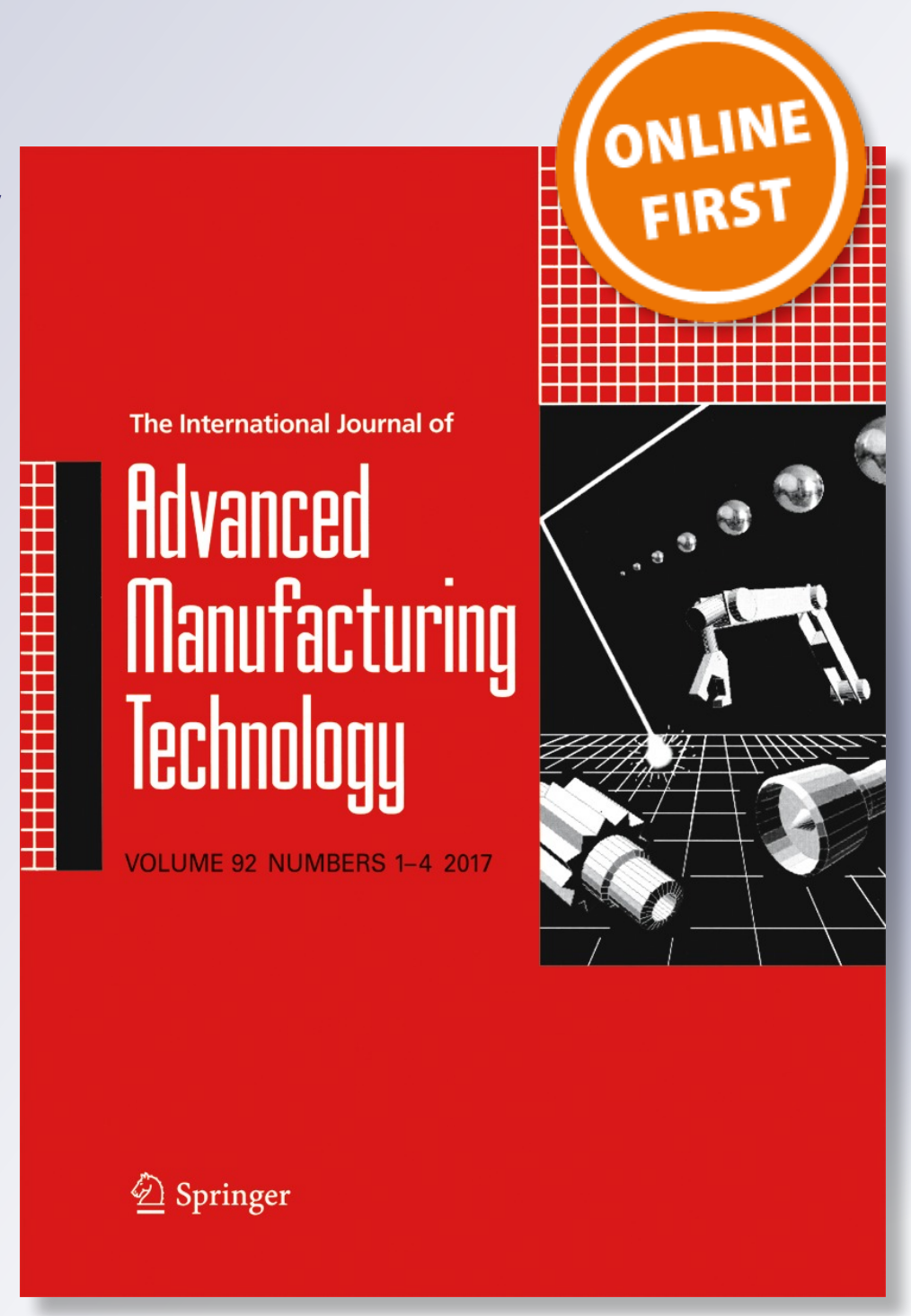

算 Springer 
Your article is protected by copyright and all rights are held exclusively by SpringerVerlag London Ltd.. This e-offprint is for personal use only and shall not be selfarchived in electronic repositories. If you wish to self-archive your article, please use the accepted manuscript version for posting on your own website. You may further deposit the accepted manuscript version in any repository, provided it is only made publicly available 12 months after official publication or later and provided acknowledgement is given to the original source of publication and a link is inserted to the published article on Springer's website. The link must be accompanied by the following text: "The final publication is available at link.springer.com". 


\title{
A review of micro-mechanical cutting
}

\author{
Brian Boswell $^{1}$ - M. N. Islam ${ }^{1}$ - Ian J. Davies ${ }^{1}$
}

Received: 20 March 2017 / Accepted: 2 August 2017

(C) Springer-Verlag London Ltd. 2017

\begin{abstract}
The need for using alternative processes rather than electro-discharge machining (EDM) for micro-parts has allowed micro-manufacturing (also known as precision engineering) to become an important option due to its speed, economy, capability and extended range of materials. One main group of micro-manufacturing processes is that of micromechanical cutting with the focus of this review being micro-mechanical cutting processes that generate chips, namely, micro-turning, micro-milling and micro-drilling. Developments and future prospects for these micromachining processes have been reviewed including microcutting configurations, cutting tools, tool coatings, cutting fluids, chip formation, surface finish, burr formation, modelling and industrial applications. The main advantages and disadvantages of these micro-manufacturing processes have been highlighted together with their future prospects.
\end{abstract}

Keywords Micro-manufacturing $\cdot$ Micro-optical systems · Micro-milling $\cdot$ Micro-turning $\cdot$ Micro-drilling $\cdot$ Precision machining

\section{Introduction}

The trend towards miniaturisation has opened up new avenues of research, most notably in the fields of electronics and biomedical devices. This movement towards micro-

M. N. Islam

M.N.Islam@curtin.edu.au

1 Mechanical Engineering, Curtin University, Bently, Perth, Western Australia 6845, Australia manufacturing has necessitated manufacturing industries to invent and adopt new processes on the micro-scale in their design and machinery systems. Although techniques for the manufacture of micro-scale parts and features have existed for many years, new requirements have made it critical for micromanufacturing to evolve and adapt. At its simplest level, micro-manufacturing is simply manufacturing to a smaller scale as the parts, and hence products, are produced on the micro-scale. It can also be referred to as precision manufacturing or precision machining due to the high degree of accuracy required [1]. A typical definition of micro-manufacturing is the manufacturing of components or devices on a micro-scale. Technically, micro-cutting can be characterised by the ratio between the unit of material removed and size of the tool edge radius, suggesting that the tool edge radius in micromechanical machining is the key element in cutting with respect to material grain size. Therefore, researchers looking for a more technical definition of micro-machining use the grain size, tool size and undeformed chip thickness to produce features on the micron scale [2].

The market for micro-manufacturing is increasing, and this has encouraged companies specialising in many different areas to develop their current processes to these requirements [3]. Whilst micro-manufacturing has the ability to be used in many industries, the electronics industry in particular has grasped the opportunities offered, which has resulted in a diverse range of parts and products including quartz resonators [4], electro-statically actuated switches [5], micro-pumps [6], interconnection systems [7], relays [8], resonator oscillators [9] and oxygen electrodes [10]. The significant challenges for micro-electronic mechanical systems (MEMS)-based manufacturing are not only due to the product but also as a result of the necessary scaling down of the tools and machinery [11]. Conventional machining, which depends on mechanical/thermal and cutting/forming, has found that 
meeting the required dimensional accuracy for micromachining is significantly more challenging and requires additional sophisticated machine features.

The micro-manufacturing industry has exhibited a growth of approximately $20 \%$ per annum since 2000 and is expected to grow at an even higher rate in the future [12] with emerging technologies likely to include further advances in laser micromanufacturing [13-17] and ultrasonic micro-cutting [18-20]. Micro-manufacturing is an industry where extensive research needs to be conducted on both new and developed processes. The continual growth of micro-machining has seen the industry developing to produce smaller products manufactured to extremely high levels of accuracy, with micro-scaled features included on normal-sized products [21, 22]. Micro-products have the ability to fulfil many roles since their environmental footprint is often negligible whereas their efficiency is generally very high. Such a phenomenon is demonstrated by the high heat transfer rate and low energy required to create motion due to their advantageous size to weight ratio [23]. When products are created on a smaller scale than is previously existing, it results in many advantages, both to the users and the product. An example of this is that moving parts are more efficient since they require less energy to move due to their reduced mass and inertia. Products will possess much faster reaction times as parts exhibit a smaller degree of physical movement, heating-up time or follow-on reaction. Having a physically smaller component also makes it much more durable and resistant to drops and vibrations as they have less inertia to cause damage [24].

The scale of micro-manufacturing is the factor which causes the majority of issues associated with producing parts. In particular, it has proved extremely challenging to produce features and measure the actual accuracy of construction [25] due to this accuracy being at an extreme level which makes almost all aspects of the process more expensive. Indeed, as the product gets smaller, the cost increases exponentially. The dashed box in Fig. 1 highlights micro-processes that produce chips and tend to be more economical than other micro-processes. These chip-generating processes will form the main focus of this review paper due to the increasing interest of manufacturers and researchers in these areas, in addition to their growing practical adoption by manufactures.

\subsection{Micro-manufacturing}

Over the past 20 years, there has been an increasing interest in micro-manufacturing $[27,28]$, resulting in a large number of papers being published across numerous research areas [23, 26, 29, 30]. Within this wide expanse of research, the current review will focus on research specifically for micro-cutting where chips are produced [23]. Figure 2 shows micro-turning/milling and drilling documents found on Scopus between 1990 and 2016 with the search being refined to consider documents only from engineering micro-cutting applications [31].

For many years, milling has proved to be an extremely versatile process in the traditional scale of machining [32], and when material conditions are pertinent, micro-milling is increasingly popular to use. Micro-milling is fortunate to share many of the same attributes as conventional milling, which has resulted in it being one of the fastest growing processes in the micro-manufacturing industry. This popularity has led to a large number of research studies being completed. Micro-milling is an extremely versatile process which allows the machining of hard [33] and soft [34] materials as well as non-conductive [35] materials. It has become an increasingly viable option for machining hardened steel [36] as its material removal rate is up to five times that of competing processes such as electro-discharge machining (EDM), whilst still maintaining good dimensional
Fig. 1 Classification of micromanufacturing processes with the dashed box indicating scope of this review (adapted from [26])

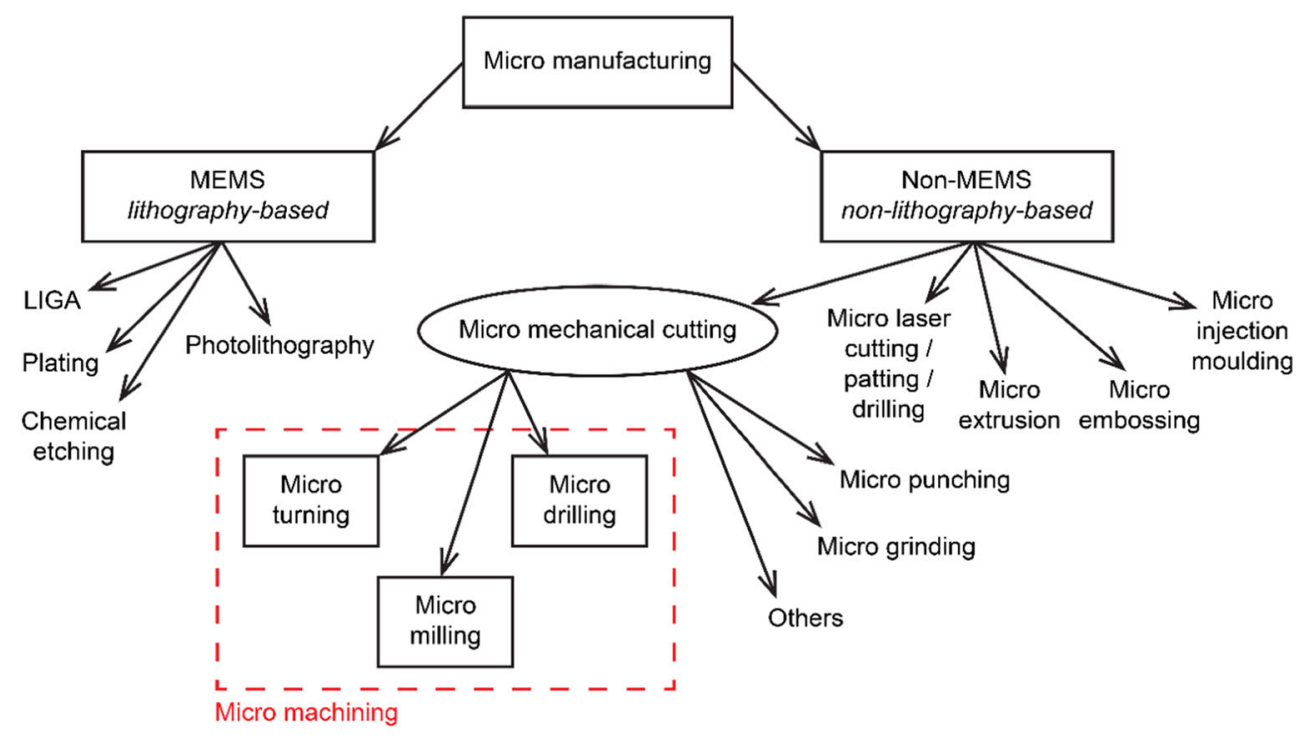




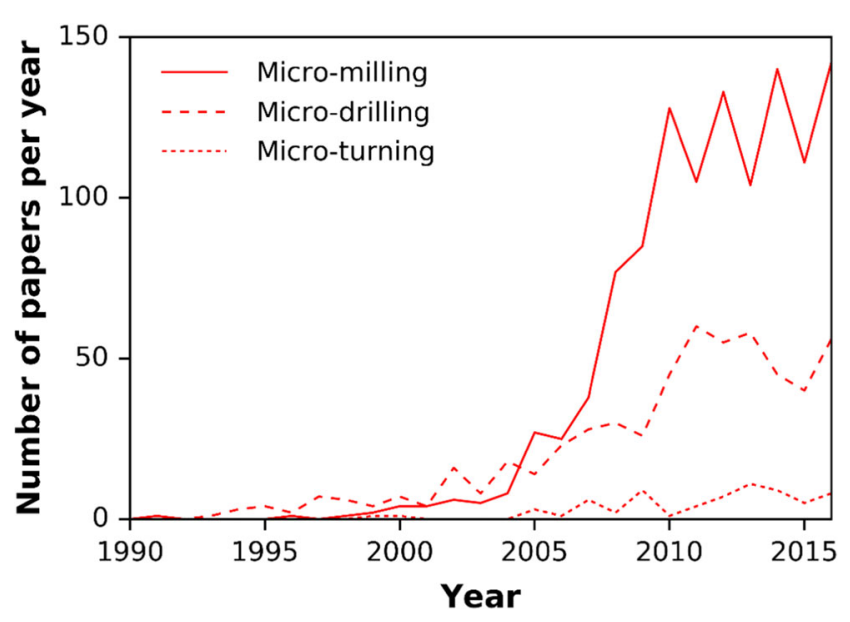

Fig. 2 The number of papers published on "micro-milling", "microdrilling" and "micro-turning" [31]

accuracy. However, significantly more research and development is required on the cutting tools, and in particular on the cutting edge [32-34, 37] and tool coatings [35, 38], to further understand and reduce tool wear. As tool coatings are further developed, the applications for micro-milling will be expected to grow considerably [36, 39]. Although micro-machining processes are relatively new, there are questions concerning the direction in which the industry will go in the future, and which processes will continue to flourish. It is expected that future methods will be focussed towards precision machining aspects rather than the production of micro-scaled parts [40].

An example of an extremely hard material is tungsten which is classified as being hard to machine [41]. It has many varied properties which is why it is one of the most popular materials used for producing tool tips. Whilst the popularity of using ceramics for micro-machining [42] has increased in recent years, mainly due to their extremely high hardness, this also makes them a difficult material to machine due to their brittle nature and tendency to crack or chip [43]. It is this extreme hardness that makes it a very desirable material for use in machining tool tips, which are often coated or layered with ceramic to increase their hardness [44].

\section{Cutting tools}

The tools used for all traditional micro-machining techniques are critical to all properties produced by the process, as they are the parts which are physically touching the material. Micro-cutting tools are essentially similar to those of common cutting tools but scaled down to a micro-size. Conversely, these tools require a much higher degree of accuracy to compensate for the tolerance errors in very small parts. The most common method for ensuring the correct accuracy is through vision-based measurement. A high-quality camera used in conjunction with a personal computer is the most effective, cheapest and fastest way to ensure a tool has been constructed to the correct dimensional accuracy [45]. The most common issue found through these measurement techniques is unwanted vibration, which leads to poor accuracy of the part or else breakage of the tool [46]. Various techniques can be implemented to monitor the tool's condition to ensure it does not have any issues that may affect the end product. These techniques involve vibration and noise sensors that pick up any irregular patterns, as well as the monitoring of chip flows produced by cutting. Such techniques will indicate early signs of tool deterioration [47]. Vibration is a major issue when constructing micro-tools, as very small vibrations can disrupt their production. However, it can also be employed as an advantage to produce certain features in the tools such as sharp points or curves using non-traditional processes such as electrochemical machining [48]. The most common types of micro-tools used are tungsten carbide tools due to their high hardness and strength when subjected to high temperatures. Although diamond micro-tools are often used for ultraprecision tools, they do not cut ferrous materials very efficiently because of the resulting excessive wear.

Figure 3 is an example of the many different types of machining tools employed in micro-machining processes. Each of these tools has a different use which may possess both

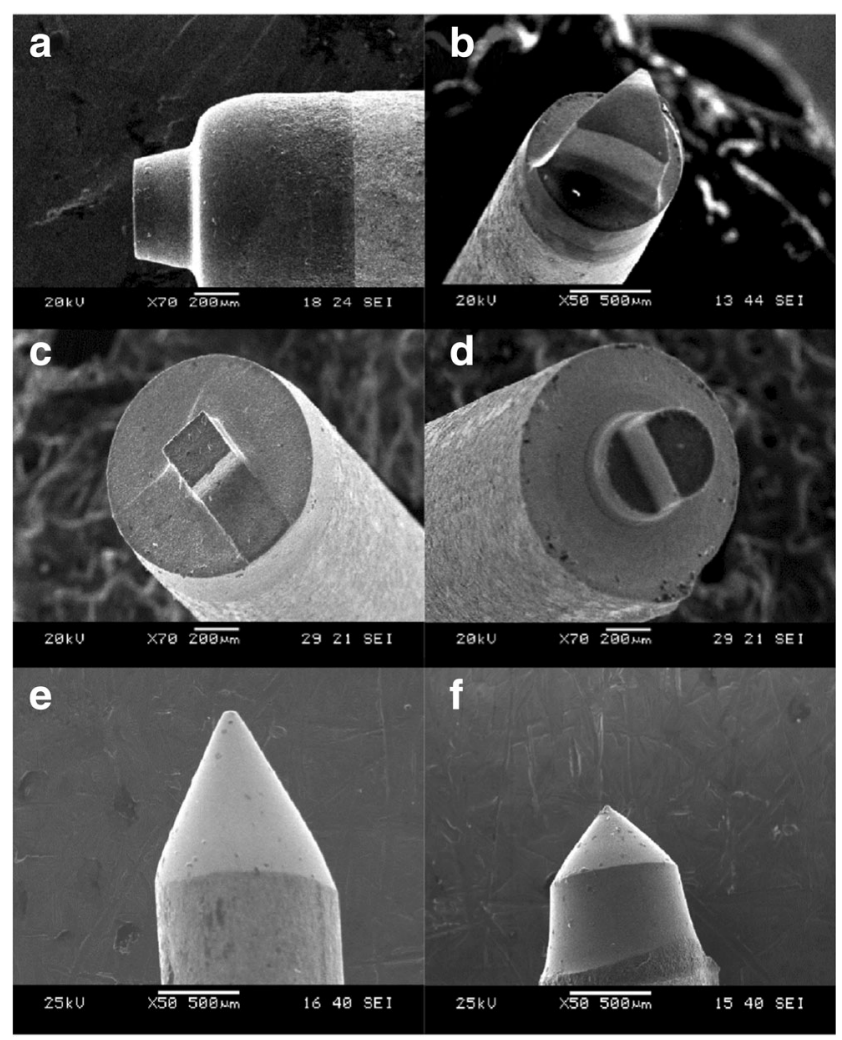

Fig. 3 Scanning electron micro-graphs illustrating examples of different tool shapes: a circular, b triangular, c square, $\mathbf{d}$ D-shaped, e conical $30^{\circ}$ and $\mathbf{f}$ conical $45^{\circ}[49]$ 
advantages and disadvantages, such as strength and cutting efficiency, or the ability to produce certain features. Polycrystalline diamond tools are diamond tools which have a random crossed grain shape, which results in the tool life and durability being significantly greater compared to that of other micro-tools [41]. Importantly, the positive attributes that these micro-tool materials possess, in turn, make it difficult to manufacture. As broken tools can have a dramatic effect on the workpiece, it is very important that early signs of tool breakage are constantly monitored. The primary monitoring techniques are in the form of vibration, acoustic and cutting force sensors which detect changes in the normal patterns created [50]. However, the main concern with these sensors is that they must be located very close to the tool, and consequently very close to the lubricant, chips and other obstacles, which can often damage the sensor or compromise their effectiveness [51].

The effect of tool wear in conventional machining is somewhat negligible due to the tolerances being too large for tool wear to make a significant impact. However, in micro-machining, the tolerances are extremely small so tool wear can have a significant impact on the process. In normal machining, tool wear is something that is compensated for by increasing the force at the tool's cutting tip. However, in the case of micro-machining, the tools are extremely small and fragile [28] and thus can easily break if excessive force is used. It is very important that the micro-tools are checked regularly to maintain the high standards of accuracy needed for the process. Tool wear is something that can be monitored and controlled, depending on which materials are being machined and the type of machining process being employed. It is critical in micro-machining that tool wear is kept to a minimum as it will significantly affect the accuracy of the product [52]. Numerous research studies have been completed on different tool materials to combat the issue of tool wear and prolong tool life, such as the combining of different materials to produce a micro-tool with the positive attributes required.

Figure 4 illustrates the influence of cutting length on two micro-cutting tool bits. Whereas the tool used for $190.5 \mathrm{~mm}$ of cutting length (Fig. 4a) still has very straight cutting edges and very little damage, indicating that it is still in excellent condition and able to produce accurate cuts, the tool with the longer cutting length (Fig. 4b) has worked material embedded onto its surface and no longer has straight cutting edges, thereby indicating substantial wear, and resulting in higher cutting forces and poor accuracy [53], making replacement necessary.

Figure 5 illustrates the phenomenon of micro-tools being fragile and possessing deformations that can affect the tool's ability to cut accurately. Micro-tools are subject to residual stresses and hence become deformed causing the end of the tool to bend. Tools in this condition are no longer usable, as the accuracy required in parts is no longer obtainable for micro-scaled products [54]. In response to this issue, new

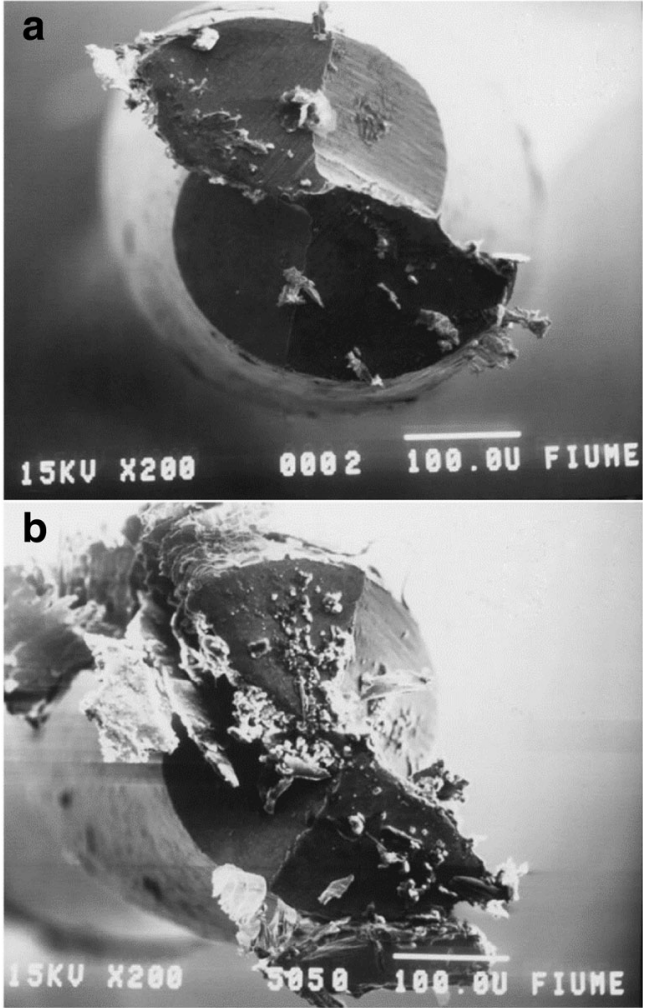

Fig. 4 Scanning electron micro-graphs illustrating the influence of cutting length on cutting tool wear: a 190.5 and b $444.5 \mathrm{~mm}$ [53]

techniques for the manufacture of micro-tools have been proposed such as laser hardening followed by micro-milling [55].

Figure 6 shows the effect of abrasive wear occurring from the physical machining process. This wear reduces surface finish accuracy and requires more energy to produce a cut. Although wear cannot be avoided, using a harder, more wear-resistant micro-tool, is the best option for reducing the amount of abrasive wear on tools [56].

Figure 7 shows an example of crater wear on a microcutting tool with Fig. 7a illustrating how the crater begins as a small pitting, then quickly develops into a much deeper crater. In contrast to this, Fig. 7b shows how the crater was about to breach the edge of the tool, which would reduce the tool's accuracy and surface finish of the product [57].
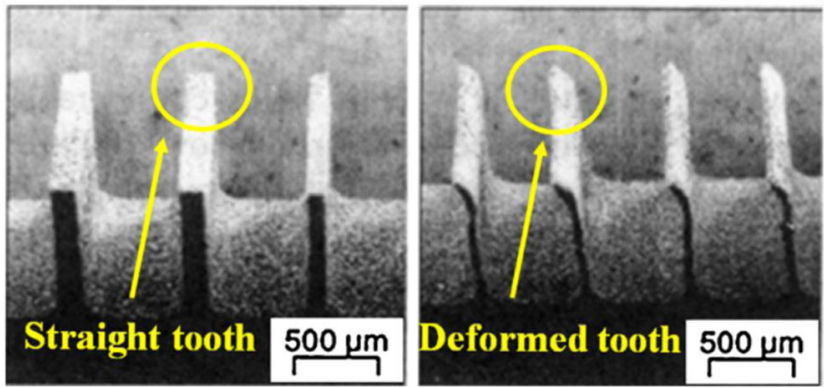

Fig. 5 Scanning electron micro-graphs illustrating deformation of microtools due to residual stresses [54] 


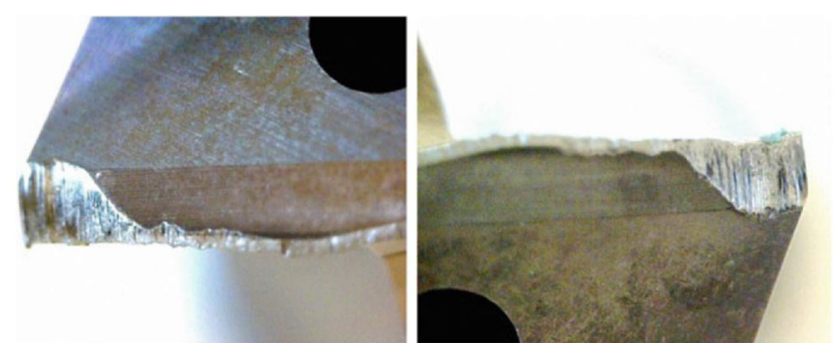

Fig. 6 Optical micro-graphs illustrating abrasive tool wear [56]

Figure 8 shows a tool which has sustained flank wear caused by abrasion and adhesion between the micro-tool and workpiece. When material debris from the hard tool or workpiece ends up getting caught between the tool and workpiece surface, flank wear, as shown, results [58]. Micro-milling tools are subject to large amounts of wear, which quickly causes the tools to be unusable due to the extreme accuracy required for the production of quality micro-products. The main reason why micro-tools are susceptible to large amounts of wear is the extremely high rotational speeds which are commonly used in the process. The speeds mean that the tools can cut more material, which in turn increases their exposure and amount of wear [59]. Premature tool wear is a common reason for shortened tool life as it makes the cutting edge wear unpredictably. This is often the main cause of tool breakage. One way to combat this phenomenon is to ensure good edge preparation, which includes the dimensions and shape of the edge as well as how it is produced. Particular edge shapes will perform better than others depending on the cut being made, which makes the edge geometry critical. How the edge is created can significantly impact the tool life as any imperfection can cause the tool to fail [60].

Figure 9 shows the difference in a micro-tool cutting edge between brand new (left) and after machining $140 \mathrm{~mm}$ (right). Although the difference may appear relatively minor, it will cause the accuracy of the workpiece to drop off and the surface finish created to diminish. If this tool continues to be used, the cutting forces will need to be increased, which will risk tool breaking or chipping [61].

Figure 10 shows how the progression of flank wear occurs and also that, when it is observed at different stages, it can be plotted and consequently modelled with a reasonable amount of accuracy. The process would involve taking multiple

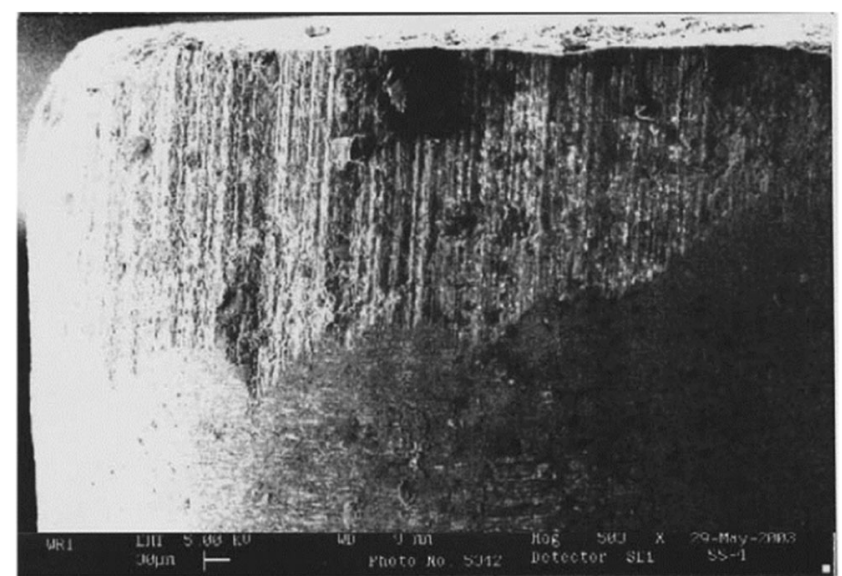

Fig. 8 Scanning electron micro-graph illustrating flank wear on a tool [58]

measurements from different stages and calculating whether any form of correlation exists [62].

Chatter is a common type of vibration which is self-excited by the interaction between the tool and workpiece and can result in a poor surface finish and increased tool wear. As the tool is so small in micro-milling, it is often easily broken when chatter occurs which can quickly ruin both the tool and part [63]. It can be diagnosed through examining the surface finish and observing a poor material removal rate from a damaged tool. The vibrations creating the chatter can also be observed through sensors; however, being micro-scaled parts, they can often be extremely small in amplitude and thus difficult to detect [64].

\section{Cutting fluid}

Traditional machining uses cutting fluid which is necessary for a satisfactory material removal rate or when high amounts of heat need to be removed. However, due to its environmental and often toxic characteristics, alternative methods of cooling the workpiece have been researched. For instance, a relatively new technique of using chilled air with a vapour lubricant mix has been trialled with good success. It has shown that cooler working conditions make the process more efficient, causing less wear on the tools through significantly
Fig. 7 Optical micro-graphs illustrating crater tool wear [57]
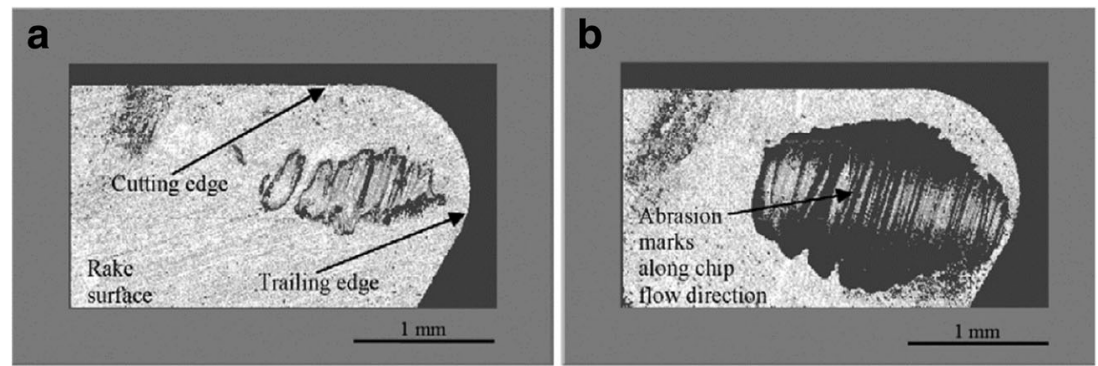


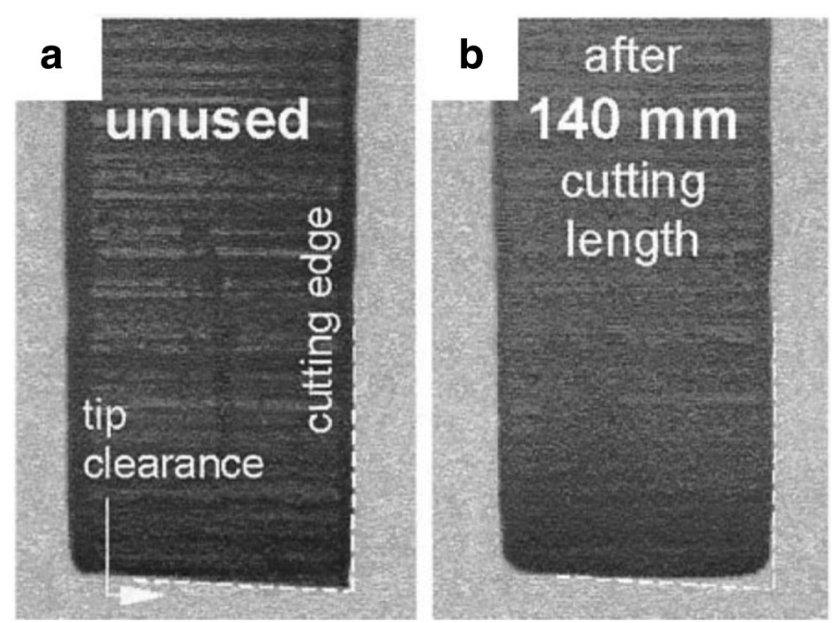

Fig. 9 Optical micro-graphs illustrating tool wear on a cutting edge: a unused and $\mathbf{b}$ after 140-mm cutting length [61]

reducing the cutting forces. More environmentally friendly fluids are now being researched as they can cut costs and are not as hazardous as the traditional alternatives [65].

There are many safety issues present when it comes to the use of cutting fluids, and as such various aspects need to be considered when the selection is made [66]. This is why it is very important to select a fluid which is not only good for production but safe for the operator. One alternative is to use vegetable oils which are considerably safer for the operator and cleaner to dispose of [67]. Using additives and modifications to the vegetable oil's composition can result in chemical reactions which improve the oil [68]. The development of less toxic additives includes lignin, which is a chemical compound produced from wood and is one of the most common organic polymers available [69].

Figure 11 demonstrates the effect that a cutting fluid, such as canola oil, can have on the chips produced from machining. These differences in chip size show how canola oil-based fluid also results in a more precise chip formation, which will significantly improve workpiece accuracy [70].

Figure 12 illustrates the significant effect that canola-based cutting fluid has on tool wear. Further research is being conducted to discover how to improve the effects of using cutting fluids. New dry lubrication technology is also being developed, in particular graphite nanoplatelets which are sprayed or coated on the grinding material surface. Studies have already shown significant reductions in both heat and cutting forces caused by the grinding process [71].

\section{Tool coatings}

Tool coatings have been used extensively in the machining industry for many years and are now being developed and adapted for use in the micro-machining industry. The greatest difficulty with this technique is that the thin coatings have a significant impact on the dimensions of the tools which are already very small and thus may possibly affect the cutting radius. However, the major benefit of using coatings is that they allow tools themselves to have the improved properties of a specific material, without having to make the entire tool out of it, thus reducing the cost significantly [36]. In particular, coatings are commonly used in micro-milling to increase a tool's durability and make it more suitable for machining, in particular for hard materials. There are many different types of coatings available such as those based on titanium, diamond [41, 72-74], silicon carbide or boron nitride [75]. Whilst the coating improves the tool's ability to machine, it also increases the cutting forces due to the increased cutting edge radius of the tool [76]. The impact of this will largely depend on the thickness of the coating applied [77].

Coating a micro-tool gives it many advantages over a standard uncoated tool, such as the ability to be used at higher cutting speeds, increasing the material removal rate, higher wear resistance and an increase in resistance to chemicals [78]. Diamond coatings are often used to utilise the extreme hardness and wear properties of the diamond. However, adhesion between the diamond and the tool material is very difficult due to the large difference in hardness. This often results in the diamond coating breaking off and exposing the tool material [79].

Other common types of tool coatings used are ceramic and tungsten. Ceramic coatings are widely used because of their high hardness, good temperature resistance and their reasonable cost. In recent times, ceramic coatings have been combined with other materials to produce coatings with a greater range of properties [80]. Examples of this are the cermet coatings which consist of silicon nitride with a crystalline nitride surface structure. This gives a very high hardness and temperature resistance, and makes cermet coatings very effective at cutting

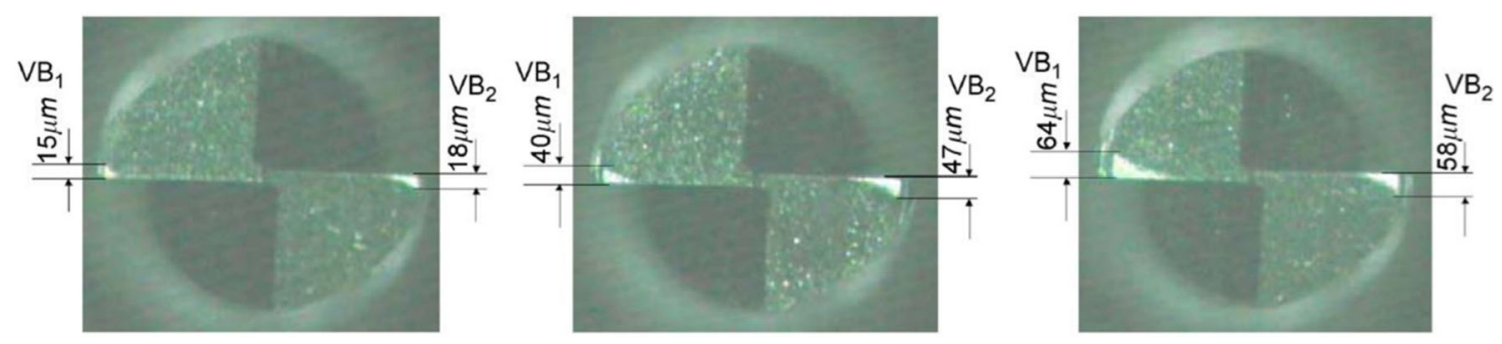

Fig. 10 Optical micro-graphs illustrating flank wear on an 800- $\mu$ m-diameter milling tool [62] 
Fig. 11 Scanning electron micrographs illustrating the effect of canola oil on chip size and shape compared to dry cutting and conventional cutting fluid $\left(\mathrm{TRIM}^{\circledR}\right)$ [70]

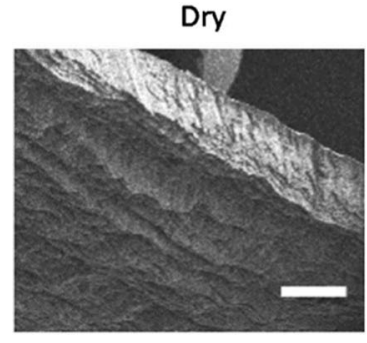

TRIM 5\%

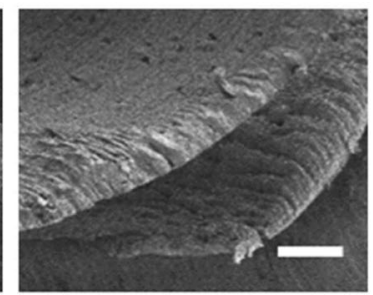

Canola oil-in-water

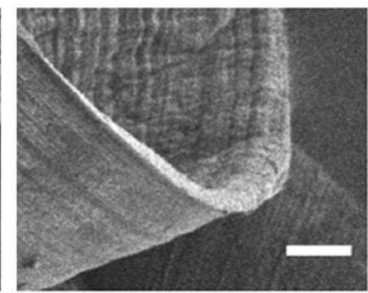

alloy steel. Tungsten thin film coating is a coating used, like other coatings, to gain the properties of a tungsten tool without having to make the entire tool out of tungsten. Use of the coating contributes towards reducing cost and gives the product the properties of a tungsten tool and a very high hardness of up to $4000{ }^{\circ} \mathrm{C}[81]$.

The thickness of the coatings used is also very important and needs to be very carefully considered for the task the tool is required to complete. Thicker coatings are usually more wear resistant and longer lasting, although they put more force on the tool, increasing the chance of breakage [82]. The outer edges of the cutting surfaces have a much harder and more durable diamond coating protecting the carbide tool [83]. The use of monolayer coatings has its advantages and is also relatively inexpensive. Multilayer coatings are becoming increasingly more common and a tool can have many different types of coatings layered on top of each other in either thick or thin layers. However, coatings comprised of many layers are found to increase the radius of the cutting edge.

Figure 13 indicates how the multilayer coating is far superior to monolayer coatings with respect to cracking. This is due to the layers dispersing the load and allowing different coatings to share their beneficial characteristics. For example, using a very brittle material with a more ductile material in order to gain the benefit of each characteristic or property [84].
Figure 14 shows the dramatic effect a coating can have on the amount of wear a tool withstands. There is a considerable difference between the wear of the uncoated tool (Fig. 14a) and the $\mathrm{CrN}$-coated tool (Fig. 14b) and an even large difference for the $\mathrm{Cr}_{0.37} \mathrm{Al}_{0.63} \mathrm{~N}$-coated tool (Fig. 14c). This indicates how a coating can make a difference, but as it becomes more refined and more research is conducted, the coatings will continue to improve [85].

\section{Micro-cutting configuration}

As micro-machining increases in popularity, there is an evergrowing demand for machining to be conducted within a shorter time period [86, 87]. This is where traditional machining ideology has its greatest benefits. It is relatively fast and cost effective in comparison to many of the other nontraditional techniques [88]. Traditional micro-machining is the process in which the machining process is completed with the same original cutting characteristics [23]. As such, material is chipped or ground off to create the desired shape. However, the micro-machining tools and processes have to be changed and adapted and not just scaled down in size.
Fig. 12 Optical micro-graphs illustrating the tool wear effect of cutting fluids (dry cutting, conventional cutting fluid $\left(\right.$ TRIM $\left.^{\circledR}\right)$ and canola oil) [70]

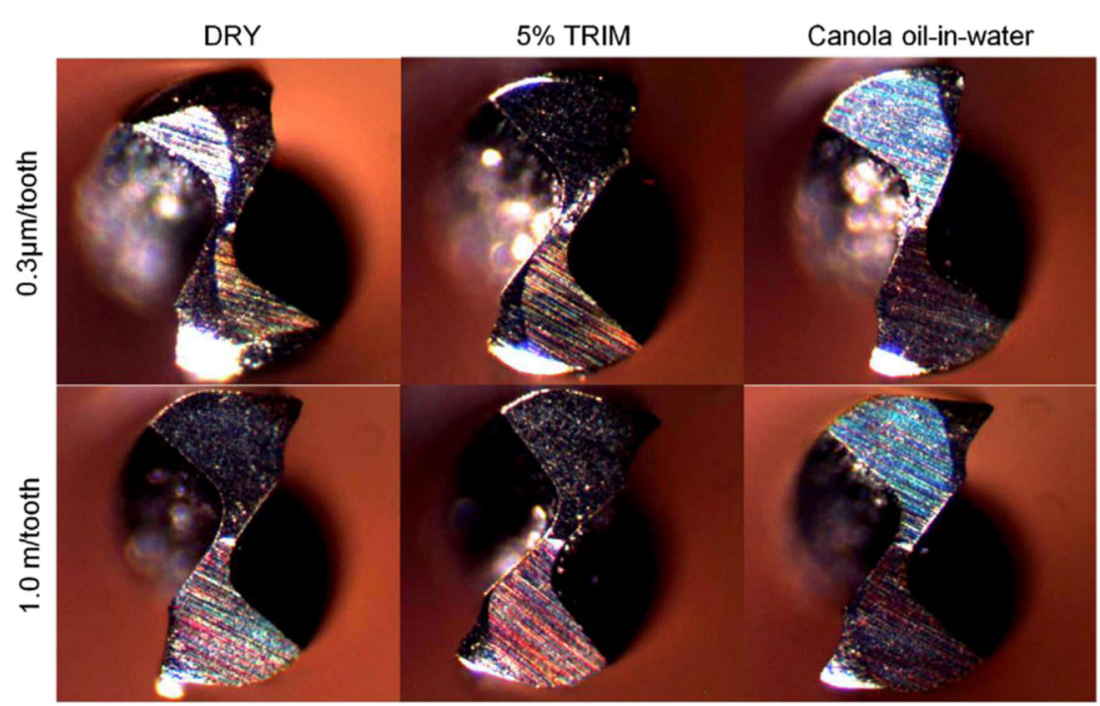




\section{Mono-layer Coating}

Small obstruction of crack extension; Crack peaks run to substrate-surface

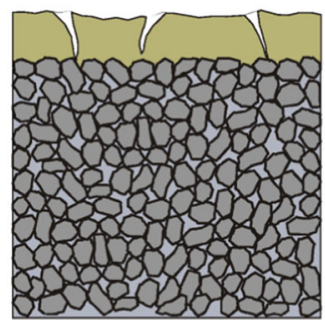

Multi-layer Coating

Reduction of crack energy by crack deflection and branching

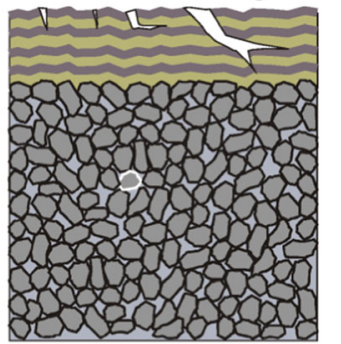

Fig. 13 Schematic representation of mono- and multilayer coatings [84]

\subsection{Micro-turning}

Micro-turning is very similar to traditional turning. However, it requires a very balanced machine and needs to be extremely accurate (often called "ultraprecision machining"). It is a physical machining process which provides a very good surface finish due to the fact that diamond cutting tools are often used allowing almost any material to be machined. The most important quality of a micro-turning tool is considered to be the tool's dynamic stiffness, which is the ratio of the applied force to the displacement [89]. This is due to the fact that, in micro-turning, the tool is constantly under pressure and gaining heat from friction as it cuts. The largest issue with micro-turning is tool breakage which can be caused by many different factors with the most common one being chatter. This is generally a result of improper machine rigidness and materials not having consistent properties [90].

Typically, a micro-lathe is constructed very much like a traditional lathe but with much smaller and more precise parts. However, there does exist some fundamental differences with, for instance, a tool dynamometer being incorporated into the lathe to measure the cutting force exerted on the micro-tool, in order to help reduce breakages. It is also common for an

optical microscope and a monitor to be present to allow the operator to see the product in detail during machining [91, 92]. Tests have shown that cutting speed, feed rate and depth of cut have a direct impact on cutting forces and surface roughness during a process. As with traditional lathe work, cutting speed and depth of cut have an impact on the generated forces. The critical force is produced by the feed rate, having the most significant impact, and must be monitored to ensure the tool is not damaged [93]. The surface roughness is almost completely influenced by feed rate alone, being $90 \%$ more influential on the resulting surface as per traditional lathe work. This means that the cutting speed and depth of cut must be adjusted to suit the required feed rate to achieve a particular finish [94]. Monitoring is extremely important in performing a successful micro-turned part. However, there now exists advanced models that can predict with reasonable accuracy many of the cutting forces and material removal rates [95]. Even though this is the case, further research is still needed to ensure that the models are accurate enough to be depended upon in practical applications. In addition, newer configurations have been developed such as micro-turn-milling which indicated improved shape quality compared to micro-turning by itself [96].

\subsection{Micro-milling}

Micro-milling is very similar to traditional milling except that the spindle speeds used are faster than those for traditional milling. Extreme accuracy is necessary as even very small errors will cause serious issues. Micro-milling is a developing micro-process due to the range of applications it can be used for [97]. It is being actively researched due to its potential to replace micro-EDM. Micro-milling has been proven to provide better accuracy whilst also having a material removal rate of up to five times that of micro-EDM [38]. New machines are being developed called ultramills, which have the ability to
Fig. 14 Optical micro-graphs illustrating comparisons in wear for different coating types [85]

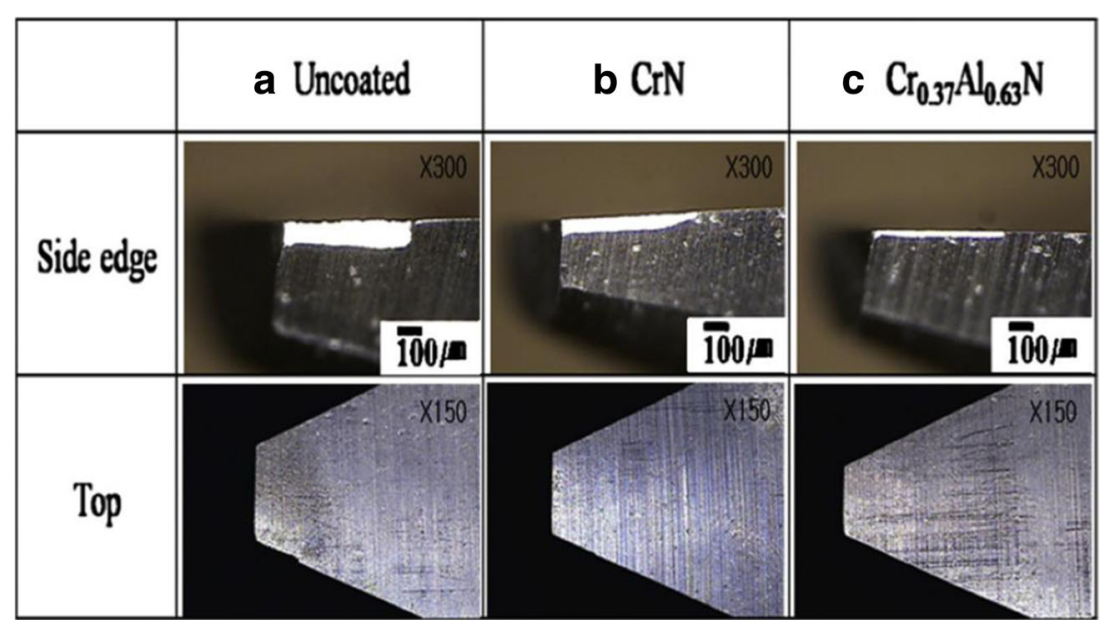


produce products with very high tolerances [98]. The machines presently being developed are six-axis machines rather than the more common three-axis or five-axis machines. This allows a huge amount of freedom in the production stages [99].

Micro-milling is a process which has many advantages and has quickly become the preferred option for micro-machining processes. In general, micro-milling is defined as a milling process which can machine features which are on the microscale, or where $1 \mu \mathrm{m}$ will make a difference to design accuracy [100]. Micro-milling is an extremely flexible process which has the ability to perform numerous tasks and produce many different shapes and features on its workpiece. The process works through having a workpiece being held in a stationary position whilst a spindle rotates a tool and moves it along the $X, Y$ and $Z$ axes. This provides for a very versatile machining process, although the material removal rates are often relatively low [101]. The tools range from 25 to $1000 \mu \mathrm{m}$. However, as the tools get smaller they become harder to purchase or manufacture. Micro-milling requires very high spindle speeds, with speeds in excess of $100,000 \mathrm{rpm}$ being proposed [102, 103], which has the advantage of being able to create $3 \mathrm{D}$ parts without having to move and reclamp the workpiece and which eliminates possible movement errors. With more modern and advanced machines being developed, such as six-axis pole machines over the standard three-axis machines, the variety of part designs able to be produced on a single machine is becoming more advanced and makes micro-milling ever more suitable to multiple applications [104].

Figure 15 is a photograph of two tools, namely a conventional 6-mm milling slot cutter (left) and $200-\mu \mathrm{m}$ cutter (right). This demonstrates the sheer scale of the differences between the two processes. Although they are essentially completing the same task, the size of the micro-milling process creates many challenges with important aspects including

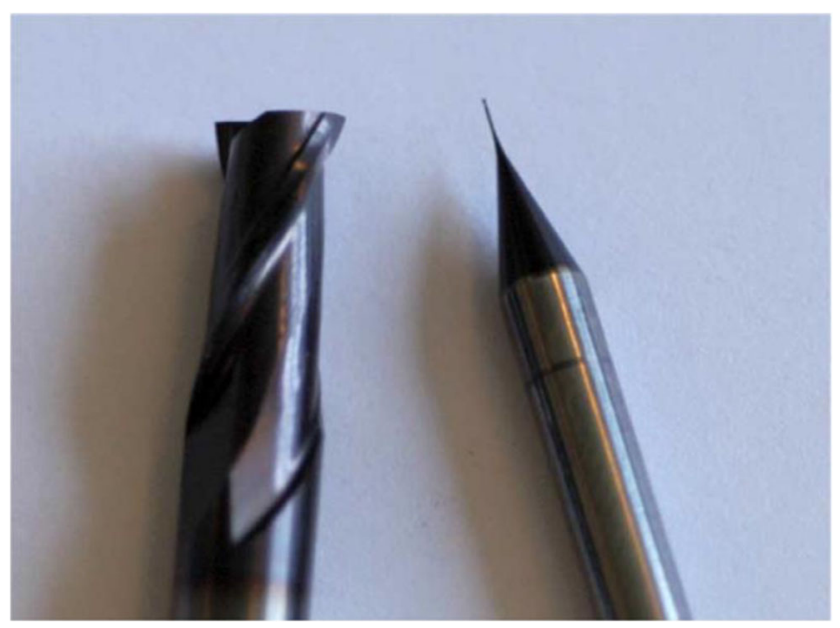

Fig. 15 Optical photograph illustrating the difference in scale between milling (left) and micro-milling (right) tools [105] controlling the cutting forces and accuracy [105-109]. Micromilling works using a very similar process to conventional milling but on a much smaller scale. It removes material through mechanical force and abrasion, which means that material is removed with plastic and brittle deformation. A highly concentrated force is used to stress the material and this in turn can cause breakage. This force is supplied by the milling machine and the tool rotational speed, which is why higher spindle speeds are often used to reduce the force on the tool. Many aspects such as tool vibration and deflection must be monitored to ensure the process runs smoothly [110].

Unlike traditional milling, the vibrations in micro-milling are almost always caused by the tool itself rather than the force of the tool interacting with the workpiece. The cutting forces in micro-milling are extremely small, and as such do not generate the vibrations associated with traditional milling [111]. The tools in micro-milling are subject to large amounts of wear, causing their accuracy to diminish relatively quickly. Premature tool wear is the most common type, and it is unpredictable and quickly diminishes the accuracy and tolerances of a workpiece. To help combat this, various coatings are often used to decrease the wear rate [60]. Whilst the regular three-axis mill can only move within the $\mathrm{X}, \mathrm{Y}$ and $\mathrm{Z}$ planes, the five-axis mill can also move with a rotatory action around the $X$ and $Z$ axes, giving it the ability to produce more complex parts $[99,112,113]$. The basic design of a five-axis micro-milling machine allows it to produce $3 \mathrm{D}$ products whereas other processes may not have this ability.

Tools in micro-milling play an extremely important role in producing a quality part. Establishing the correct angles and dimensions is key to enabling the micro-milling cutter to be effectively used. The cost of making tools to the required size and accuracy is extremely high [114]. As very high temperatures are generated between the tool surface and workpiece, the tool must be made of a material which reduces diffusion. This is why materials with very high hardness at extreme temperatures are used such as diamond and titanium [115, 116]. The design of the tool can limit or expand its capabilities through the use of different materials or coatings to enhance durability and life [74]. The shape of the tool also affects its performance. A rounded tool will produce a better surface finish and a smaller burr compared to a sharp or chipped tool [117].

Simply downscaling milling tools to the micro-scale has proven not to be successful as the shapes are too complex [118]. The main techniques used to create the tools are EDM-based, as this can be used to cut very hard materials which are ideal for milling tools. The shape of the micromilling tool is the key to making the machine work economically and effectively. To develop the tool and assess its effectiveness, the tools are constructed with a simulation software which eliminates many of the issues to be found before the physical production commences [119]. 
Diamond tools are also a very common type of tool used as they possess the properties needed to cut and machine extremely hard materials such as ceramics. Diamond tools are usually produced through laser machining and have shown a sufficiently high accuracy for the production of moulds [120]. A focused ion beam has also been used for many years in the manufacturing of traditional milling tools and it has been successfully refined to produce micro-tools. Further development is needed though for the production of extreme tool sizes [121].

Tool deflection is a common issue with micro-milling as the size of the tools makes them susceptible when exposed to cutting forces. This deflection will result in poor accuracy if not managed and monitored appropriately. The amount of deflection can be predicted, observed and monitored through mathematical models which take into account the tool dimensions, materials and cutting forces present. The amount of deflection must be managed to ensure that accuracy standards are met [122-124]. Minimising the amount of deflection in the tool can be done through increasing the rotational speed. This is due to the tool cutting faster and reducing the cutting forces needed for the milling operation. Deflection, however, is not only found in the tool as it can also be present due to the micro-milling machine not being sufficiently rigid to resist the forces [125].

The sharpness of the cutting tool plays a critical role in the surface quality of the workpiece. When using a diamond cutting tool, the sharpness has a significant effect on the surface roughness, surface hardness and the residual stresses within the workpiece. This is caused by the cutting edge radius changing as the tool becomes blunt over time. Just as in traditional machining, a sharper tool will produce a better quality surface in comparison to a blunt tool [126]. Tool radius is a key factor in the effectiveness and sharpness of a tool. If the tool is relatively round it will require higher cutting forces to complete the task and, as the micro-tools are very small, it increases the chance of a tool breaking or being damaged.

\subsection{Micro-drilling}

Micro-drilling is the process of producing holes less than $50 \mu \mathrm{m}$ in diameter with a micro-tool. Micro-drilling has not had the same amount of research conducted in comparison to other techniques used to produce micro-holes due to the fact that the drilling tools needed have complex shapes and geometries [114]. Micro-drilling is extremely efficient in comparison to other drilling techniques and can produce much deeper holes, although unfortunately flat bottoms are not possible.

The biggest concern with micro-drilling is the breaking of the micro-drill from thrust forces with sensors being added to combat this issue. Vibration is also a major cause of tool breakage and is often caused by the drill's outer corners experiencing excessive wear and fracturing. As the rotational drilling speeds are significantly faster than those found with a traditional process, acoustic sensors are used to avoid breakage problems [114]. The vibrations and excessive thrust forces found in micro-drilling can also cause poor accuracy. The most common way to combat this is to use the cutting in method in which the tool cuts into the workpiece and then pulls back, releasing its contact with the workpiece before making contact and cutting again. This allows the tool to release its thrust forces and reduce the time spent experiencing vibrations caused by the cutting process. Tests have proven this to be successful [127].

The smallest drill bit constructed, just $3 \mu \mathrm{m}$ in diameter, has never been successfully used as it failed in all test drilling stages. The smallest hole drilled was $6.7 \mu \mathrm{m}$ across, drilled with a $6-\mu \mathrm{m}$ diameter bit. Any drill bit smaller than this was not able to produce a hole prior to failure occurring [128] with the drilling of smaller hole diameters requiring the use of more exotic processes such as electro-chemical micro-drilling [129, 130] and ultrafast laser micro-drilling [131, 132]. To reduce the size of the thrust force in micro-drilling, the bit is rotated at speeds of almost $100,000 \mathrm{rpm}$ [80]. These high rotational speeds reduce the force by allowing the drill to cut much faster. However, the drill bit must also be extremely sharp so that it cuts effectively and efficiently. Whilst micro-drilling is a downscaled process of conventional drilling machine, the fundamental aspects such as cutting force, feed rate and chip thickness cannot be scaled with any degree of accuracy [133].

Figure 16 shows the general arrangement of a microdrilling system. This includes many of the features that are normal to a traditional drilling arrangement such as the drill bit, green body (workpiece), backup plate, jig and lubricant. There are other items used which are also needed for the micro-drilling operation to occur, such as the dynamometer which measures the amount of force on the tool, thus keeping the force below a specific level to avoid breaking the drill bit. Extra lubricant is used, not only to reduce the forces on the drill bit but also to maintain the temperature of the tool to be as cool as possible as the drill bit is extremely small and can heat up very quickly [134].

\section{Modelling}

Simulation is often used to predict the forces and whether or not the tool can be used without any issues [135]. Modelling the micro-milling process through the use of analytical methods and complex algorithms is gaining support, with more research being completed to increase the reliability of the results obtained [136]. Computer models can be used to predict the amount of tool wear and the force at which the tool will break [113]. This has been completed with an error of $21 \%$, the error mainly being attributed to the generally unpredictable wear rates following some form of tool failure [137]. 
Fig. 16 Schematic illustration of a typical micro-drilling arrangement [134]

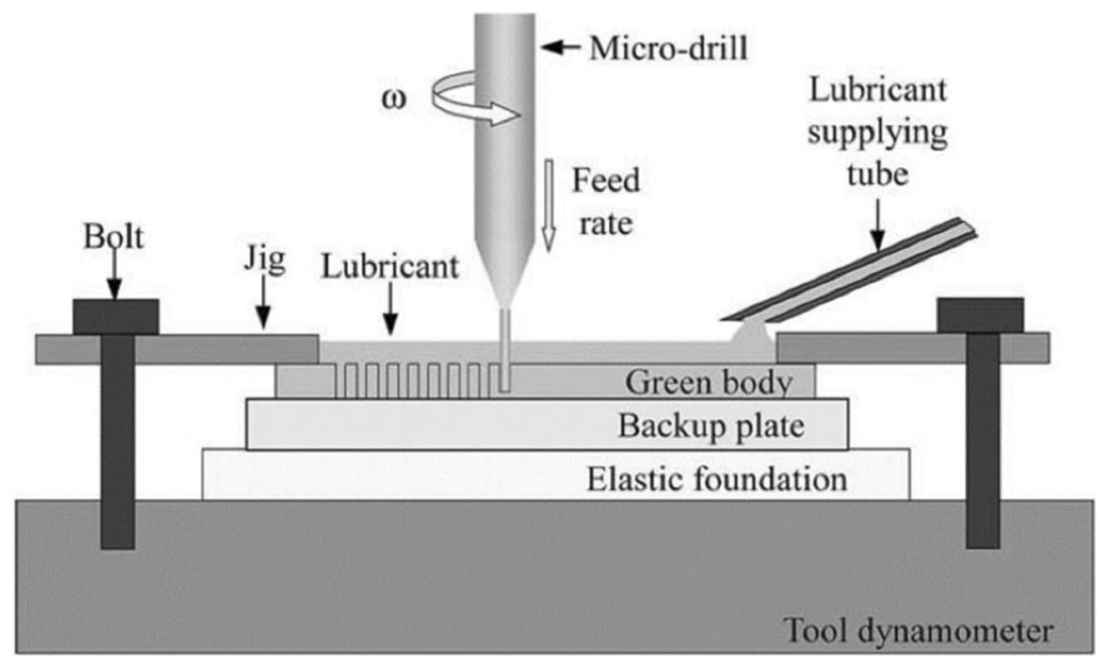

However, this does give an advantage to being able to predict the tool lifespan and what forces it will be able to withstand over that lifetime. Whilst the testing for modelling is being completed, much of the information being collected allows for a better understanding of how to make the process more efficient and effective with different materials. Once the actual modelling process is completed, it also has the advantage of being able to further refine the efficiencies seen during testing [138]. It can help to evaluate whether micro-milling is a viable process for the applications needed by being able to test different-shaped tools with diverse cutting techniques to an accuracy of up to $10 \%$ in comparison with physical testing. It makes the process much cheaper by not needing to physically build and test every tool, whilst still obtaining a reasonably accurate result from the tool modelling [139].

After test cuts, the tools are measured and the wear is recorded in order to develop a more accurate model. This allows the optimum cutting angle and edge radius to be developed [140]. The process is expensive and time consuming but hugely benefits future micro-milling models. Surface generation micro-end milling models are useful in examining the five fundamental aspects that influence the machined surface roughness, namely (1) process kinematics, (2) process dynamics, (3) cutting edge geometry, (4) elastic recovery and (5) minimum chip thickness. Burr formation factors have to still be introduced into the models making further research necessary to improve accuracy $[87,141]$.

\section{Micro-cutting process}

\subsection{Chip formation}

The chip thickness is very important in micro-milling as it controls many aspects of how the finished product will turn out in terms of surface finish and quality of work. Material can be removed through ploughing, cutting or slipping, with each process changing the surface finish and the forces exerted on the tool [142-145]. The minimum chip thickness is reliant on the sharpness of the tool and the material being machined. Different materials will have different minimum chip thicknesses needed to produce the desired surface finish [29].

Figure 17 demonstrates how material is removed through chipping, but as the diagram on the right shows, sometimes no chip is created. This is an issue with micro-milling as the tool is relatively blunt when compared to traditional milling processes and very small amounts of material are removed at any given time. This effect is often called ploughing and causes plastic deformation on the surface of the workpiece [147]. Chip formation is key to understanding metal removal for micro-machining. For example, researchers examined microend milling chips from a range of materials using different machining parameters [2] and found that the specific acoustic energy increased as the ratio of the underformed chip thickness to width of cut increased [148].

\subsection{Surface finish}

Surface finish in micro-machining is extremely important as it often determines the quality of the workpiece produced because it has a large influence on its strength and accuracy. The major factors influencing the surface finish in micro-milling are the spindle speed, material removal rate and depth of cut. These must be carefully managed and monitored to ensure a
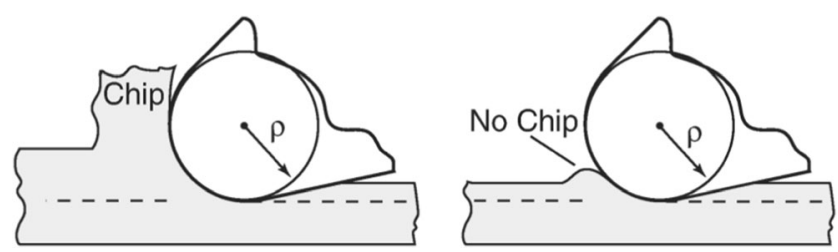

Fig. 17 Schematic illustration of micro-tool chip removal [146] 
suitable surface finish is being applied [149]. Much of the surface quality in micro-milling is controlled by the chip thickness and formation. If the chip thickness is less than the cutting edge radius, it will cause poor surface roughness. This is caused by the elastic recovery of the material.

The spindle speed and feed rate have been shown to control chip formation and surface finish. With a lower feed rate, the spindle speed has little effect on the finish $[150,151]$. However, at higher feed rates, the spindle speed plays a significant role in achieving the desired finish [146]. The surface finish created from a flat-end milling tool leaves lines and, if not spaced correctly, can ruin the surface of a product. Generally, the lines left from the previous cut are removed with the new cut [152].

Surface finish is not only dependent on the tool used and speed at which it cuts. The materials used also play a significant role in the quality of the finish achieved. For example, fine-grained steel has the ability to produce a much higher quality surface finish than larger grained steel. However, the fine-grained steel will also be prone to indentation and cause higher frictional forces on the tool [153]. The material removal rate has a significant effect on many aspects of the process, such as required surface finish produced and ultimately machining time. In general, a larger radius cutting tool and higher spindle speed will result in a higher material removal rate. As a result, to keep the material removal rate constant, the feed rate is often increased or decreased, depending on the tools used [154].

\subsection{Burr formation}

Burring commonly occurs in both normal and microtraditional machining processes and results from the unwanted protrusion of material caused by plastic deformation in a cutting or shearing process [155-157]. If chatter is observed, the resulting vibration will lead to burr formation and catastrophic failure, indicating that a layer of the material is not cut properly and must be removed as shown in Fig. 18 which illustrates top and exit burrs caused by micro-milling. These burrs occur from advancing plastic deformation caused by the cutting tool. As the tool reaches an edge where there is little resistance, the plastically deformed material gets forced over the edge and creates the burr [158]. Burr formation is principally the major damage observed on machining a surface subjected to micro-milling. Also significant is tool run-out which contributes significantly to noise in force measurement, surface quality and extensive vibrations causing burr formation.

Removing this burr is often extremely expensive, especially as the ratio of burr to workpiece size increases. The cost of removing the burr is often in excess of $30 \%$ of the total machining cost for the part [159]. The problem with removing the burr is that with the micro-scale of the workpiece it is very

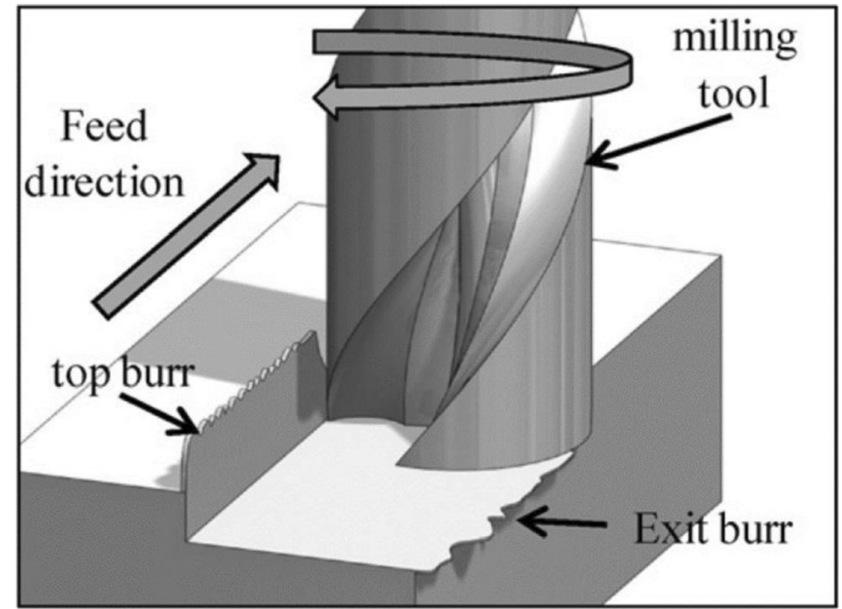

Fig. 18 Schematic illustration of top and exit burrs [158]

difficult to remove the burr without damaging the workpiece itself.

With the use of traditional methods applied to a microscale, there will often be residual stresses applied and accuracy issues created by the removal of the burr. With these factors present, it is best to reduce the initial size of the burr created in the machining process [157]. A reasonably simple way to do this is by altering the feed rate and tool dimensions. It has been shown that when the feed rate is increased the burr size decreases, and also when the radius of the cutting tool increases the burr size decreases [141]. However, when burr creation cannot be avoided and thus must be removed, the most effective method used is micro-EDM machining. It has the ability to remove very small pieces of material without physically touching the workpiece and causing unwanted residual stresses. It can also remove extremely hard materials just as easily as soft materials. However, EDM machining can only remove burrs which are from an electrically conductive material [160].

\section{Industrial applications}

Micro-milling is recognised as a viable option for micro-machining, since its high material removal rate is becoming increasingly popular for creating 3D products using hardened materials. It is being used to create micro-dies and moulds [161] because it can complete the mould or die much faster than other methods whilst still producing them with excellent accuracy [162]. For example, diamond tools used in micromills have been shown to be successful in producing tungsten carbide moulds [163].

As well as in micro-milling operations, special tools can be used to remove material in a micro-grinding milling process. This is when the tool has a grit coating on the rear faces of the cutting edges, which allows a grinding process to be completed after the conventional milling process is finished. This is 
Table 1 Typical micro-machined applications

\begin{tabular}{|c|c|c|c|}
\hline Part/workpiece & Geometry feature & Micro-process & Material \\
\hline Micro-cups & $\begin{array}{l}\text { Less than } 1 \mathrm{~mm} \text { in } \\
\text { diameter, various } \\
\text { thicknesses }\end{array}$ & $\begin{array}{l}\text { Micro-machining } \\
\text { Micro-deep } \\
\text { drawing } \\
\text { Micro-stamping } \\
\text { Micro-spinning }\end{array}$ & $\begin{array}{l}\text { Molybdenum } \\
\text { Copper } \\
\text { Aluminium } \\
\text { Steel }\end{array}$ \\
\hline Micro-gears & $\begin{array}{l}\text { Diameters less than } \\
1 \mathrm{~mm} \text {, features } \\
\text { less than } 10 \mathrm{~s} \text { of } \\
\text { microns }\end{array}$ & $\begin{array}{l}\text { Micro-machining } \\
\text { Micro-forging } \\
\text { Micro-extrusion } \\
\text { Micro-casting } \\
\text { EDM }\end{array}$ & $\begin{array}{l}\text { Metals } \\
\text { Polymers }\end{array}$ \\
\hline Shafts & $\begin{array}{l}\text { Less than } 1 \mathrm{~mm} \text { in } \\
\text { diameter }\end{array}$ & $\begin{array}{l}\text { Micro-machining } \\
\text { Micro-extrusion }\end{array}$ & $\begin{array}{l}\text { Steel and } \\
\text { alloys }\end{array}$ \\
\hline $\begin{array}{l}\text { Micro-screws } \\
\text { Micro-cans }\end{array}$ & $\begin{array}{l}\text { Diameters of } 0.1 \text { to } \\
0.5 \mathrm{~mm}\end{array}$ & $\begin{array}{l}\text { Micro-machining } \\
\text { Micro-forging } \\
\text { Micro-extrusion }\end{array}$ & $\begin{array}{l}\text { Various } \\
\text { metals }\end{array}$ \\
\hline $\begin{array}{l}\text { Micro-gear } \\
\text { shafts }\end{array}$ & $\begin{array}{l}\text { Features of } 30 \text { to } \\
\quad 40 \mu \mathrm{m}\end{array}$ & $\begin{array}{l}\text { Micro-machining } \\
\text { Micro-forging } \\
\text { Micro-extrusion } \\
\text { EDM }\end{array}$ & Metals \\
\hline $\begin{array}{l}\text { Micro-moulds, } \\
\text { dies and } \\
\text { punches } \\
\text { Tool tips }\end{array}$ & $\begin{array}{l}\text { Die-bore or inner } \\
\text { pockets in less } \\
\text { than } 1 \mathrm{~mm} \text {; } \\
\text { punch diameter } \\
\text { from } 0.05 \text { to } \\
1 \mathrm{~mm}\end{array}$ & $\begin{array}{l}\text { Micro-machining } \\
\text { Sintering } \\
\text { EDM } \\
\text { Laser cutting }\end{array}$ & $\begin{array}{l}\text { Tool steel } \\
\text { Tungsten } \\
\text { Stainless } \\
\quad \text { steel } \\
\text { Glass } \\
\text { Ceramics }\end{array}$ \\
\hline
\end{tabular}

usually completed to improve the surface quality for parts used in micro-products such as drones. Although this is a relatively new application and process, it has huge potential [164]. Table 1 gives examples of parts/workpieces that micromachining can be used for.

Micro-cutting has also been applied to biomedical applications such as titanium dental implants $[93,165]$ where surface features of metal implants [166] were modified to influence cell adhesion [167]. Micro-cutting can also be used to modify the surface tribology of metals through the incorporation of micro-grooves [18, 168], micro-dimples [169] and other micro-patterns $[170,171]$. In addition, micro-cutting has been used to machine challenging materials such as glass $[168,172$, 173] and calcium fluoride [174].

Fabrication of deep X-ray lithography masks is a new application in which micro-milling is being applied to, rather than using other manufacturing methods. This is in a large part due to the significant time reduction which can be established through using a milling process. Micro-milling has been used to create workpieces with a depth of $62 \mu \mathrm{m}$ and a width of $8 \mu \mathrm{m}$. This makes micro-milling more than adequate for the task of producing micro-lithography masks [175].

The consensus derived from the papers reviewed is that micro-cutting is important in the machining of $3 \mathrm{D}$ workpieces with complex geometries. Macro-phenomena such as chatter, burr factors, tool wear, monitoring and workpiece handling all
Table 2 Key micro-machining research areas

\begin{tabular}{|c|c|c|}
\hline Research area & Remarks & References \\
\hline Micro-tools & $\begin{array}{l}\text { Very expensive to produce } \\
\text { Coated tools }\end{array}$ & {$[36,38,44,80-82,85]$} \\
\hline Chip formation & $\begin{array}{l}\text { Tool radius to depth } \\
\text { of cut ratio } \\
\text { Tool geometry } \\
\text { Chip thickness } \\
\text { Mode of cutting }\end{array}$ & $\begin{array}{c}{[2,49,105,117,118} \\
126,147,176]\end{array}$ \\
\hline Cutting forces & $\begin{array}{l}\text { Cutting force } \\
\text { Chip thickness } \\
\text { Maximising tool } \\
\text { deflection error } \\
\text { Specific acoustic energy }\end{array}$ & $\begin{array}{l}{[23,26,30,59,77,89} \\
92,94,106-108, \\
122-124,140]\end{array}$ \\
\hline Modelling & Chips and forces & $\begin{array}{l}{[29,54,90,95,97,} \\
\quad 104,109,136,138, \\
139,141,142]\end{array}$ \\
\hline Tool wear & $\begin{array}{l}\text { Tool wear prediction } \\
\text { Tool wear monitoring } \\
\text { Effect of tool wear }\end{array}$ & $\begin{array}{c}{[23,38,47,48,53,62} \\
\quad 66,78,120,177]\end{array}$ \\
\hline Burring & $\begin{array}{l}\text { Burr formation rate on } \\
\text { tool life }\end{array}$ & {$[1,2,23,30]$} \\
\hline $\begin{array}{l}\text { Machining } \\
\text { dynamics }\end{array}$ & $\begin{array}{l}\text { Measurement system } \\
\text { Frequency domain }\end{array}$ & $\begin{array}{l}{[51,59,63,64,90,} \\
\quad 93,127]\end{array}$ \\
\hline $\begin{array}{l}\text { Workpiece } \\
\text { materials }\end{array}$ & $\begin{array}{l}\text { Hardness and strength } \\
\text { 3D shape from a variety } \\
\text { of materials }\end{array}$ & $\begin{array}{l}{[2,23,29,33-35,42} \\
\quad 43,79]\end{array}$ \\
\hline $\begin{array}{l}\text { Machine tool } \\
\text { requirements }\end{array}$ & $\begin{array}{l}\text { Micro-milling } \\
\text { Micro-turning } \\
\text { Micro-drilling }\end{array}$ & $\begin{array}{l}{[2,4,23,25-27,29,} \\
\quad 30,96,98,99,104]\end{array}$ \\
\hline
\end{tabular}

need further investigation. In the previous section, details of micro-cutting tools, machine tools, micro-cutting and auxiliary processes were examined. The micro-machining research surveyed identified nine fundamental areas which are summarised in Table 2 which also identifies relevant papers.

\section{Conclusions}

The micro-manufacturing industry possesses huge potential to grow and expand as the world demand for micro-parts increases. This demand has already encouraged the advancement of new research and developments in many of the cutting processes used. Achieving the high level of machine accuracy has resulted in:

- The development of ultraprecision machine tools that are necessary to achieve a good surface finish and accurate workpiece

- Tool wear being identified as a major concern, as this contributes substantially to the dimensional accuracy of the micro-parts

- Continued research into aspects of tool coatings and materials shown to be necessary for efficient tool application 
Sustainable cooling and lubrication of the cutting interface has been identified as an essential element in the micro-cutting of hard-to-machine materials and helps reduce plastic deformation.

- Using graphite nanoplatelets sprayed onto the workpiece warrants further investigation.

- As surface roughness and burr are parameter dependent, it is essential to be aware that optimum conditions for one may result in an unacceptable outcome of the other.

- Most research reports that cubic boron nitride-coated micro-tools improve the temperature and tool wear and reduce burr formation

- An advantage of micro-milling is that it can produce 3Dfree form surfaces unlike many other processes such as micro-laser beam machining and lithographic techniques.

Another benefit from using micro-cutting processes is the range of materials that can be machined such as:

- Steel, aluminium, brass

- Ceramics, glass

- Plastics, polymers

In summary, the cost of the machining setup for the processes investigated in their review is less than that of many other micro-manufacturing processes, allowing micro-parts to be produced at an economical cost. Also, the future for machining of parts will require new six-axis pole machines which are necessary to provide effective machining of everincreasing complex workpieces.

Acknowledgments The authors would like to gratefully acknowledge Kieren Petchell who contributed to this paper as part of an undergraduate project.

\section{References}

1. Chern G-L, Wu Y-JE, Cheng J-C, Yao J-C (2007) Study on burr formation in micro-machining using micro-tools fabricated by micro-EDM. Precis Eng 31:122-129

2. Mian AJ, Driver N, Mativenga PT (2011) Chip formation in microscale milling and correlation with acoustic emission signal. Int J Adv Manuf Technol 56(1):63-78

3. Waurzyniak P (2013) Micro manufacturing keeps shrinking the envelope. Manuf Eng 150:65-73

4. Godshall NA, Koehler DR, Liang AY, Smith BK Micro-machined resonator, U.S. Patent 5,198,716, filed December 9th 1991 and issued March 30th 1993 https://www.google.com.au/patents/ US5198716. Accessed 8 August 2017

5. Larson LE Micro-machined switch and method of fabrication, U.S. Patent 5,121,089, filed November 1st 1990 and issued June 9th 1992 https://www.google.com.au/patents/US5121089. Accessed 8 August 2017
6. Kamisuki S, Nose Y, Shimizu N, Yotsuya S Micropump with valve structure, U.S. Patent 5,259,737, filed July 2nd 1991 and issued November 9th 1993 https://www.google.com.au/patents/ US5259737. Accessed 8 August 2017

7. Herndon TO, Raffel JI Interconnection system for high performance electronic hybrids, U.S. Patent 5,345,365, filed May 5th 1992 and issued September 6th 1994 https://www.google.com.au/ patents/US5345365. Accessed 8 August 2017

8. James CD, Katzenstein HS Micromachined relay and method of forming the relay, US Patent 5,479,042, filed February 1st 1993 and issued December 26th 1995 https://www.google.com.au/ patents/US5479042. Accessed 8 August 2017

9. Koehler DR, Sniegowski JJ, Bivens HM, Wessendorf KO Micromachined resonator oscillator, US Patent 5,339,051, filed March 30th 1993 and issued August 16th 1994 https://www.google.com. au/patents/US5339051. Accessed 8 August 2017

10. Suzuki H, Sugama A, Kojima N Oxygen electrode and temperature sensor, US Patent 5,431,806, filed November 17th 1993 and issued July 11th 1995 https://www.google.com.au/patents/ US5431806. Accessed 8 August 2017

11. Qin Y (2015) Chapter 1-overview of micro-manufacturing. In: Qin Y (ed) Micromanufacturing engineering and technology (Second Edition), ed New York: William Andrew Publishing, pp 1-33

12. Uhlmann E, Piltz S, Doll U (2005) Machining of micro/miniature dies and moulds by electrical discharge machining - recent development. J Mater Process Technol 167:488-493

13. García-López E, Medrano-Tellez A, Ibarra-Medina J, Siller Héctor R, Elías-Zúñiga A, Rodríguez Ciro A (2016) Fiber laser microcutting of AISI 316L stainless steel tubes-influence of pulse energy and spot overlap on back wall dross. Procedia CIRP 49:222-226

14. Eberle G, Dold C, Wegener K (2015) Laser fabrication of diamond micro-cutting tool-related geometries using a high-numerical aperture micro-scanning system. Int J Adv Manuf Technol 81:11171125

15. Demira AG, Previtalia B (2015) Microcutting of multi-layer foils with IR and green ns-pulsed fibre lasers for Li-ion batteries. Procedia CIRP 33:526-531

16. Eberle G, Dold C, Wegener K (2015) Picosecond laser fabrication of micro cutting tool geometries on polycrystalline diamond composites using a high-numerical aperture micro scanning system. In: Klotzbach U, Washio K, Arnold CB (ed) Laser-based Microand Nanoprocessing IX - Proceedings of SPIE - The International Society for Optical Engineering, Bellingham, USA 9351:9351031-935103-9 https://doi.org/10.1117/12.2075420

17. Genna S, Leonea C, Palumbo B, Tagliaferri F (2015) Statistical approach to fiber laser microcutting of NIMONIC ${ }^{\circ}$ C263 superalloy sheet used in effusion cooling system of aero engines. Procedia CIRP 33:520-525

18. Zhang C, Guo P, Ehmann KF, Li Y (2016) Effects of ultrasonic vibrations in micro-groove turning. Ultrasonics 67:30-40

19. Wang X, Hu J (2017) Nanowire cutting by an ultrasonically vibrating micro tool. Precis Eng 48:152-157

20. Wang X, Hu J (2015) Ultrasonic cutting of individual silver nanowires by a linearly vibrating micro tool. In Proceedings of the 2015 Symposium on Piezoelectricity, Acoustic Waves, and Device, Applications, Institute of Electrical and Electronics Engineers, New York, pp. 67-69 https://doi.org/10.1109/ SPAWDA.2015.7364442

21. Qin Y, Brockett A, Ma Y, Razali A, Zhao J, Harrison C, Pan W, Dai X, Loziak D (2010) Micro-manufacturing: research, technology outcomes and development issues. Int J Adv Manuf Technol 47:821-837

22. Brinksmeier E, Preuss W (2012) Micro-machining. Philos Trans R Soc Lond A Math Phys Eng Sci 370:3973-3992 
23. Chae J, Park SS, Freiheit T (2006) Investigation of micro-cutting operations. Int J Mach Tools Manuf 46(3-4):313-332

24. Johnstone RW, Parameswaran M (2004) An introduction to surface-micromachining. Springer Science \& Business Media, New York https://doi.org/10.1007/978-1-4020-8021-0

25. Liu X (2012) In situ metrology system for micro-milling machine. J Manuf Syst 31:15-21

26. Piljek P, Keran Z, Math M (2014) Micromachining-review of literature from 1980 to 2010. Interdiscip Description Complex Syst 12:1-27

27. Mishima N, Ashida K, Tanikawa T, Kaneko K, Maekawa H, Tanaka M (2000) Study on design evaluation of machine tools for the microfactory. Kikai Gijutsu Kenkyusho Shoho/J Mech Eng Lab 54(6):254-261

28. Rahman M, Senthil Kumar A, Prakash JRS (2001) Micro milling of pure copper. J Mater Process Technol 116(1):39-43

29. Dornfeld D, Min S, Takeuchi Y (2006) Recent advances in mechanical micromachining. CIRP Ann Manuf Technol 55(2):745-768

30. Camara MA, Campos JC, Abrao AM, Davim JP (2012) State of the art on micromilling of materials, a review. JMST 28(8):673685

31. Document search results for "micro-milling", "micro-drilling" and "micro-turning", Scopus (www.scopus.com), Elsevier B.V., Amsterdam, The Netherlands (accessed March 17th 2017)

32. Peale F (1836) Description of a machine for milling coin, invented and introduced into the mint of the United States. J Frankl Inst 22(6):375-377

33. Cheng X, Wang Z, Nakamoto K, Yamazaki K (2010) Design and development of PCD micro straight edge end mills for micro/nano machining of hard and brittle materials. J Mech Sci Technol 24(11):2261-2268

34. Chen P-C, Pan C-W, Lee W-C, Li K-M (2014) An experimental study of micromilling parameters to manufacture microchannels on a PMMA substrate. Int J Adv Manuf Technol 71(9-12):16231630

35. Lu C, Gu A, Li M, Yang S (2012) The micro-milling machining of Pyrex glass using the electrochemical discharge machining process. Adv Mater Res 403-408:738-742

36. Aramcharoen A, Mativenga PT, Yang S, Cooke KE, Teer DG (2008) Evaluation and selection of hard coatings for micro milling of hardened tool steel. Int J Mach Tools Manuf 48(14):1578-1584

37. Uhlmann E, Oberschmidt D, Löwenstein A, Kuche Y (2016) Influence of cutting edge preparation on the performance of micro milling tools. Procedia CIRP 46:214-217

38. De Cristofaro S, Funaro N, Feriti GC, Rostagno M, Comoglio M, Merlo A, Stefanini C, Dario P (2012) High-speed micro-milling: novel coatings for tool wear reduction. Int J Mach Tools Manuf 63:16-20

39. Özel T, Thepsonthi T, Ulutan D, Kaftanoğlu B (2011) Experiments and finite element simulations on micro-milling of Ti-6Al-4V alloy with uncoated and cBN coated micro-tools. CIRP Ann Manuf Technol 60(1):85-88

40. Uhlmann E, Oberschmidt D, Kuche Y, Löwenstein A, Winker I (2016) Effects of different cutting edge preparation methods on micro milling performance. Procedia CIRP 46:352-355

41. Zhong L, Li L, Wu X, He N (2017) Micro cutting of pure tungsten using self-developed polycrystalline diamond slotting tools. Int J Adv Manuf Technol 89(5-8):2435-2445

42. Hu H, Zhai Z, Li Y, Wang H, Dai J (2015) Researches on physical field evolution of micro-cutting of steel H13 by micron scale ceramic cutter based on finite element modeling. Int J Adv Manuf Technol 78:1407-1414

43. Ueda K, Sugita T, Hiraga H, Iwata K (1991) A J-integral approach to material removal mechanisms in microcutting of ceramics. CIRP Ann Manuf Technol 40:61-64
44. Jianxin D, Zhenxing D, Dongling Y, Hui Z, Xing A, Jun Z (2010) Fabrication and performance of $\mathrm{Al}_{2} \mathrm{O}_{3} /(\mathrm{W}, \mathrm{Ti}) \mathrm{C}+\mathrm{Al}_{2} \mathrm{O}_{3} / \mathrm{TiC}$ multilayered ceramic cutting tools. Mater Sci Eng A 527:1039-1047

45. Wang S-M, Lin J-J (2013) On-machine volumetric-error measurement and compensation methods for micro machine tools. Int $\mathrm{J}$ Precis Eng Manuf 14:989-994

46. Imran M, Mativenga PT, Withers PJ (2012) Assessment of machining performance using the wear map approach in micro-drilling. Int J Adv Manuf Technol 59(1-4):119-126

47. Tansel IN, Arkan TT, Bao WY, Mahendrakar N, Shisler B, Smith D, McCool M (2000) Tool wear estimation in micro-machining.: part I: tool usage-cutting force relationship. Int J Mach Tools Manuf 40:599-608

48. Ghoshal B, Bhattacharyya B (2013) Influence of vibration on micro-tool fabrication by electrochemical machining. Int J Mach Tools Manuf 64:49-59

49. Perveen A, San W, Rahman M (2012) Fabrication of different geometry cutting tools and their effect on the vertical microgrinding of BK7 glass. Int J Adv Manuf Technol 61:101-115

50. König W, Kutzner K, Schehl U (1992) Tool monitoring of small drills with acoustic emission. Int J Mach Tools Manuf 32:487-493

51. Takata S, Ogawa M, Bertok P, Ootsuka J, Matushima K, Sata T (1985) Real-time monitoring system of tool breakage using Kalman filtering. Robot Comput Integr Manuf 2:33-40

52. Hong X (1990) Wear behaviour and wear mechanism of ceramic tools in machining hardened alloy steel. Wear 139:439-451

53. Tansel I, Rodriguez O, Trujillo M, Paz E, Li W (1998) Micro-endmilling - I. Wear and breakage. Int J Mach Tools Manuf 38:14191436

54. Mathew R, Sundaram MM (2012) Modeling and fabrication of micro tools by pulsed electrochemical machining. J Mater Process Tech 212:1567-1572

55. Ogawa K, Tanabe H, Nakagawa H (2015) A proposal of process strategy for micro-cutting edge fabrication: effects of shape formation after laser hardening. Key Eng Mater 625:545-549

56. Davim JP (2015) In: Paulo Davim J (ed) Traditional machining processes: research advances, Berlin, Springer Berlin Heidelberg : Imprint: Springer

57. Jayal AD, Balaji AK (2009) Effects of cutting fluid application on tool wear in machining: interactions with tool-coatings and tool surface features. Wear 267:1723-1730

58. Senthil Kumar A, Raja Durai A, Sornakumar T (2006) Wear behaviour of alumina based ceramic cutting tools on machining steels. Tribol Int 39:191-197

59. Zhu K, Hong GS, Wong YS, Wang W (2008) Cutting force denoising in micro-milling tool condition monitoring. Int J Prod Res 46:4391-4408

60. Uhlmann E, Oberschmidt D, Kuche Y, Löwenstein A (2014) Cutting edge preparation of micro milling tools. Procedia CIRP 14:349-354

61. Schaller T, Bohn L, Mayer J, Schubert K (1999) Microstructure grooves with a width of less than $50 \mu \mathrm{m}$ cut with ground hard metal micro end mills. Precis Eng 23:229-235, 999

62. Zhu K, Wong YS, Hong GS (2009) Multi-category micro-milling tool wear monitoring with continuous hidden Markov models. Mech Syst Signal Process 23:547-560

63. Rahnama R, Sajjadi M, Park SS (2009) Chatter suppression in micro end milling with process damping. J Mater Process Technol 209:5766-5776

64. Afazov SM, Ratchev SM, Segal J, Popov AA (2012) Chatter modelling in micro-milling by considering process nonlinearities. Int J Mach Tools Manuf 56:28-38

65. Pham M-Q, Yoon H-S, Khare V, Ahn S-H (2014) Evaluation of ionic liquids as lubricants in micro milling - process capability and sustainability. J Clean Prod 76:167-173 
66. Cutting fluids. In Cutting Tool Technology ed: Springer London, 2008, pp 381-430

67. Shashidhara YM, Jayaram SR (2010) Vegetable oils as a potential cutting fluid - an evolution. Tribol Int 43:1073-1081

68. John J, Bhattacharya M, Raynor PC (2004) Emulsions containing vegetable oils for cutting fluid application. Colloids Surf A Physicochem Eng Asp 237:141-150

69. Zhang Y, Jun MBG (2014) Feasibility of lignin as additive in metalworking fluids for micro-milling. J Manuf Process 16:503510

70. Burton G, Goo CS, Zhang Y, Jun MBG (2014) Use of vegetable oil in water emulsion achieved through ultrasonic atomization as cutting fluids in micro-milling. J Manuf Process 16:405-413 https://doi.org/10.1016/j.jmapro.2014.04.005

71. Alberts M, Kalaitzidou K, Melkote S (2009) An investigation of graphite nanoplatelets as lubricant in grinding. Int $\mathrm{J}$ Mach Tools Manuf 49:966-970

72. Oliaei SNB, Karpat Y (2016) Fabrication of PCD mechanical planarization tools by using $\mu$-wire electrical discharge machining. Procedia CIRP 42:311-316

73. Zhong L, Li L, Wu X, He N, Zhao G, Yao C (2017) Fabrication of PCD micro cutting tool and experimental investigation on machining of copper grating. Int J Adv Manuf Technol 88:2417-2427

74. Hei H, Ma J, Li X, Yu S, Tang B, Shen Y, Tang W (2015) Preparation and performance of chemical vapor deposition diamond coatings synthesized onto the cemented carbide micro-end mills with a SiC interlayer. Surf Coat Technol 261:272-277

75. Chen JY, Jin TY, Tian YJ (2016) Development of an ultrahard nanotwinned cBN micro tool for cutting hardened steel. SCIENCE CHINA Technol Sci 59(6):876-881

76. Wu X, Li L, He N, Yao C, Zhao M (2016) Influence of the cutting edge radius and the material grain size on the cutting force in micro cutting. Precis Eng 45:359-364

77. Afazov SM, Zdebski D, Ratchev SM, Segal J, Liu S (2013) Effects of micro-milling conditions on the cutting forces and process stability. J Mater Process Technol 213:671-684

78. Upadhyaya GS (1998) Cemented tungsten carbides: production, properties, and testing. Noyes Publications, New Jersey

79. Morrell J (2009) In: Morrell J, Jackson MJ (eds) Machining with nanomaterials. Springer US, Boston

80. Smith GT (2008) In: Smith GT (ed) Cutting tool technology : industrial handbook. Springer London, London

81. Palomar FE, Zambrano PC, Gómez MI, Colás R, Guerrero MP, Castillo A (2010) Coatings made of tungsten carbide and tantalum carbide for machining tools. Vacuum 84:1236-1239

82. Qin F, Chou YK, Nolen D, Thompson RG (2009) Coating thickness effects on diamond coated cutting tools. Surf Coat Technol 204:1056-1060

83. Marcos M Advances in materials processing technologies, 2006. Trans Tech Publishers, Zurich, p 2006

84. Weinert K, Inasaki I, Sutherland JW, Wakabayashi T (2004) Dry machining and minimum quantity lubrication. CIRP Ann Manuf Technol 53:511-537

85. Kim MW, Kim KH, Kang MC, Cho SH, Ryu KT (2012) Mechanical properties and cutting performance of $\mathrm{Cr}-\mathrm{Al}-\mathrm{N}$ hybrid coated micro-tool for micro high-speed machining of flexible fine die. Curr Appl Phys 12(Supplement 2):S14-S18

86. Thepsonthi T, Özel T (2012) Multi-objective process optimization for micro-end milling of Ti-6Al-4V titanium alloy. Int J Adv Manuf Technol 63(9-12):903-914

87. Özel T, Liu X (2009) Investigations on mechanics-based process planning of micro-end milling in machining mold cavities. Mater Manuf Process 24(12):1274-1281

88. Koc M (2011) Micro-manufacturing: design and manufacturing of micro-products. Wiley, Hoboken
89. Adair K, Kapoor SG, Devor RE (2011) Development of a unique topology for a hard-turning micro-scale machine tool. J Manuf Process 13:75-84

90. Mandal S, Kumar A, Nagahanumaiah A (2012) Assessment of micro turning machine stiffness response and material characteristics by fuzzy rule based pattern matching of cutting force plots. J Manuf Syst

91. Vinayagamoorthy R, Anthony Xavior M (2011) A review on micro turning process. Int J Curr Res 3(11):174-179

92. Lu Z, Yoneyama T (1999) Micro cutting in the micro lathe turning system. Int J Mach Tools Manuf 39:1171-1183

93. Lauro CH, Ribeiro Filho SLM, Cardoso Brandão L, Paulo Davim $\mathrm{J}$ (2016) Analysis of behaviour biocompatible titanium alloy (Ti$6 \mathrm{Al}-7 \mathrm{Nb}$ ) in the micro-cutting. Measurement 93:529-540

94. Sivaraman V, Sankaran S, Vijayaraghavan L (2012) Machinability of multiphase microalloyed steel. Procedia CIRP 2:55-59

95. Piotrowska I, Brandt C, Karimi H, Maass P (2009) Mathematical model of micro turning process. Int $\mathrm{J}$ Adv Manuf Technol 45:33-40

96. Egashira K, Furukawa T, Yamaguchi K, Ota M (2016) Microcutting using a micro turn-milling machine. Precis Eng 44:81-86. https://doi.org/10.1016/j.precisioneng.2015.10.005

97. Xie J, Li YH, Yang LF (2015) Study on 5-axial milling on microstructured freeform surface using the macro-ball cutter patterned with micro-cutting-edge array. CIRP Ann Manuf Technol 64:101-104

98. Huo D, Cheng K, Wardle F (2010) Design of a five-axis ultraprecision micro-milling machine-UltraMill. Part 1: holistic design approach, design considerations and specifications. Int J Adv Manuf Technol 47:867-877

99. Huo D, Cheng K, Wardle F (2010) Design of a five-axis ultraprecision micro-milling machine-UltraMill. Part 2: integrated dynamic modelling, design optimisation and analysis. Int J Adv Manuf Technol 47:879-890

100. McKeown PA (1987) The role of precision engineering in manufacturing of the future. CIRP Ann Manuf Technol 36:495501

101. Holme NCR, Berg TW, Dinesen PG (2008) Diamond micromilling for array mastering. In Optical engineering + applications. International Society for Optics and Photonics, pp 70620J70620J-8

102. Jahanmir S, Res Z, Heshmat H, Tomaszewski M (2010) Design and evaluation of an ultrahigh speed micro-machining spindle. Mach Sci Tech 14:224-243

103. Nishikawa F, Yoshimoto S, Somaya K (2012) Ultrahigh-speed micro-milling end mill with shank directly supported by aerostatic bearings. J Adv Mech Des Syst Manuf 6:979-988

104. Cheng K (2013) Microsystem and nanotechnology series (ME20): Micro-cutting: fundamentals and applications. John Wiley \& Sons, Somerset

105. Bissacco G, Hansen HN, De Chiffre L (2005) Micromilling of hardened tool steel for mould making applications. J Mater Process Technol 167:201-207

106. Malekian M, Mostofa MG, Park SS, Jun MBG (2012) Modeling of minimum uncut chip thickness in micro machining of aluminum. J Mater Process Technol 212(3):553-559

107. Bao WY, Tansel IN (2000) Modeling micro-end-milling operations. Part I: analytical cutting force model. Int J Mach Tools Manuf 40(15):2155-2173

108. Malekian M, Park SS, Jun MB (2009) Modeling of dynamic micro-milling cutting forces. Int J Mach Tools Manuf 49(7): $586-598$

109. Li C, Lai X, Li H, Ni J (2007) Modeling of three-dimensional cutting forces in micro-end-milling. J Micromech Microeng 17(4):671 
110. Masuzawa T (2000) State of the art of micromachining. CIRP Ann Manuf Technol 49:473-488

111. Fortgang J, Singhose W, Juanes Márquez J, Perez J (2011) International Journal of Control, Automation, and Systems ICROS, KIEE and Springer

112. Bang Y-B, Lee K-M, Oh S (2005) 5-axis micro milling machine for machining micro parts. Int J Adv Manuf Technol 25:888-894

113. Sun X, Cheng K (2015) Chapter 2-micro-/nano-machining through mechanical cutting A2 - Qin, Yi. In Micromanufacturing engineering and technology (Second Edition), ed Boston: William Andrew Publishing, pp. 35-59

114. Cheng K (2013) Micro-cutting: fundamentals and applications. Wiley, Hoboken

115. Alting L, Kimura F, Hansen HN, Bissacco G (2003) Micro engineering. CIRP Ann Manuf Technol 52:635-657

116. Gao S, Pang S, Jiao L, Yan P, Luo Z, Yi J, Wang X (2017) Research on specific cutting energy and parameter optimization in micro-milling of heat-resistant stainless steel. Int J Adv Manuf Technol 89:191-205

117. Aramcharoen A, Mativenga PT (2009) Size effect and tool geometry in micromilling of tool steel. Precis Eng 33:402-407

118. Vasile MJ, Friedrich CR, Kikkeri B, McElhannon R (1996) Micrometer-scale machining: tool fabrication and initial results. Precis Eng 19:180-186 https://doi.org/10.1016/S0141-6359(96) 00024-4

119. Fleischer J, Deuchert M, Ruhs C, Kühlewein C, Halvadjiysky G, Schmidt C (2008) Design and manufacturing of micro milling tools. Microsyst Technol 14:1771-1775

120. Suzuki H, Okada M, Fujii K, Matsui S, Yamagata Y (2013) Development of micro milling tool made of single crystalline diamond for ceramic cutting. CIRP Ann Manuf Technol 62:59-62

121. Friedrich CR, Coane PJ, Vasile MJ (1997) Micromilling development and applications for microfabrication. Microelectron Eng 35: $367-372$

122. Mamedov A, Layegh SE, Lazoglu I (2015) Instantaneous tool deflection model for micro milling. Int J Adv Manuf Technol 79:769-777

123. Dow TA, Miller EL, Garrard K (2004) Tool force and deflection compensation for small milling tools. Precis Eng 28

124. Zhang X, Ehmann KF, Yu T, Wang W (2016) Cutting forces in micro-end-milling processes. Int J Mach Tool Manu 107:21-40

125. Fortgang J, Singhose W, de Juanes Márquez J, Perez J (2011) Command shaping control for micro-milling operations. Int $\mathrm{J}$ Control Autom Syst 9:1136-1145

126. Yuan ZJ, Zhou M, Dong S (1996) Effect of diamond tool sharpness on minimum cutting thickness and cutting surface integrity in ultraprecision machining. J Mater Process Technol 62

127. Yang Z, Tan Q, Wang L (2002) Principle of precision microdrilling with axial vibration of low frequency. Int J Prod Res 40: 1421-1427

128. Egashira K, Hosono S, Takemoto S, Masao Y (2011) Fabrication and cutting performance of cemented tungsten carbide microcutting tools. Precis Eng 35:547-553

129. Ahn SH, Ryu SH, Choi DK, Chu CN (2004) Electro-chemical micro drilling using ultra short pulses. Precis Eng 28:129-134

130. Mithu MAH, Fantoni G, Ciampi J (2011) The effect of high frequency and duty cycle in electrochemical microdrilling. Int J Adv Manuf Technol 55:921-933

131. Ho SF, Ngoi BKA (2004) Sub-microdrilling with ultrafast pulse laser interference. Appl Phys B Lasers Opt 79:99-102 https://doi. org/10.1007/s00340-004-1517-3

132. Knowles MRH, Rutterford G, Karnakis D, Ferguson A (2007) Micro-machining of metals, ceramics and polymers using nanosecond lasers. Int J Adv Manuf Technol 33:95-102

133. Klocke F, Gerschwiler K, Abouridouane M (2009) Size effects of micro drilling in steel. Prod Eng 3:69-72
134. Lee DG, Lee HG, Kim PJ, Bang KG (2003) Micro-drilling of alumina green bodies with diamond grit abrasive micro-drills. Int J Mach Tools Manuf 43:551-558 https://doi.org/10.1016/ S0890-6955(03)00021-X

135. Altintas $Y$, Jin X (2011) Mechanics of micro-milling with round edge tools. CIRP Ann Manuf Technol 60:77-80

136. Zhou L, Peng FY, Yana R, Yao PF, Yang CC, Li B (2015) Analytical modeling and experimental validation of micro endmilling cutting forces considering edge radius and material strengthening effects. Int J Mach Tool Manu 97:29-41

137. Bao WY, Tansel IN (2000) Modeling micro-end-milling operations. Part II: tool run-out. Int J Mach Tools Manuf 40:2175-2192

138. Jun MBG, Goo C, Malekian M, Park S (2012) A new mechanistic approach for micro end milling force modeling. J Manuf Sci Eng 134:0110061-0110069

139. Rao S, Shunmugam MS (2012) Analytical modeling of micro end-milling forces with edge radius and material strengthening effects. Mach Sci Technol 16:205-227

140. Afazov SM, Ratchev SM, Segal J (2010) Modelling and simulation of micro-milling cutting forces. J Mater Process Technol 210: 2154-2162

141. Lekkala R, Bajpai V, Singh RK, Joshi SS (2011) Characterization and modeling of burr formation in micro-end milling. Precis Eng 35(4):625-637

142. Vogler MP, Kapoor SG, DeVor RE (2005) On the modeling and analysis of machining performance in micro-endmilling, part II: cutting force prediction. J Manuf Sci Eng 126:695-705

143. Cuba Ramos A, Autenrieth H, Strauß T, Deuchert M, Hoffmeister J, Schulze V (2012) Characterization of the transition from ploughing to cutting in micro machining and evaluation of the minimum thickness of cut. J Mater Process Technol 212:594-600

144. Yoon HS, Ehmann KF (2016) Dynamics and stability of microcutting operations. Int J Mech Sci 115-116:81-92

145. Uysal A, Altan E (2015) Effect of ploughing force on cutting forces in micro-cutting with a rounded-edge cutting tool. Mater Today: Proc 2:224-229

146. Filiz S, Conley CM, Wasserman MB, Ozdoganlar OB (2007) An experimental investigation of micro-machinability of copper 101 using tungsten carbide micro-endmills. Int J Mach Tools Manuf 47:1088-1100

147. Lucca DA, Seo YW, Komanduri R (1993) Effect of tool edge geometry on energy dissipation in ultraprecision machining. CIRP Ann Manuf Technol 42:83-86

148. Mian AJ, Driver N, Mativenga PT (2011) Estimation of minimum chip thickness in micro-milling using acoustic emission. Proc Inst Mech Eng B J Eng Manuf 225(9):1535-1551

149. Wang W, Kweon SH, Yang SH (2005) A study on roughness of the micro-end-milled surface produced by a miniatured machine tool. J Mater Process Technol 162-163:702-708

150. Vogler MP, DeVor RE, Kapoor SG (2005) On the modeling and analysis of machining performance in micro-endmilling, part I: surface generation. J Manuf Sci Eng 126:685-694

151. Lee K, Dornfeld DA (2004) A study of surface roughness in the micro-end-milling process. Laboratory for Manufacturing and Sustainability

152. Bissacco G, Hansen HN, De Chiffre L (2006) Size effects on surface generation in micro milling of hardened tool steel. CIRP Ann Manuf Technol 55:593-596

153. Komatsu T, Musha Y, Yoshino T, Matsumura T (2015) Surface finish and affected layer in milling of fine crystal grained stainless steel. J Manuf Process 19:148-154

154. Kumar MS, Kannan TTM, Giridharan S, Kumar PV (2014) Optimization of micro milling parameters of Al-6082 by anova methodology. Int J Mech Eng Robot Res 3:377-382

155. Kiswanto G, Zariatin DL, Ko TJ (2014) The effect of spindle speed, feed-rate and machining time to the surface roughness 
and burr formation of aluminum alloy 1100 in micro-milling operation. J Manuf Process 16:435-450

156. $\mathrm{Wu} \mathrm{X}, \mathrm{Li} \mathrm{L}, \mathrm{He} N$ (2017) Investigation on the burr formation mechanism in micro cutting. Precis Eng 47:191-196

157. Lee K, Dornfeld DA (2005) Micro-burr formation and minimization through process control. Precis Eng 29(2):246-252

158. Saptaji K, Subbiah S, Dhupia JS (2012) Effect of side edge angle and effective rake angle on top burrs in micro-milling. Precis Eng $36: 444-450$

159. Gillespie LK (1979) Deburring precision miniature parts. Precis Eng 1:189-198

160. Jeong YH, HanYoo B, Lee HU, Min B-K, Cho D-W, Lee SJ (2009) Deburring microfeatures using micro-EDM. J Mater Process Technol 209:5399-5406. https://doi.org/10.1016/j. jmatprotec.2009.04.021

161. Li HS Method of manufacturing a precision micro-filter, US Patent US5256360A, October 26th 1993

162. Takács M, Verö B, Mészáros I (2003) Micromilling of metallic materials. J Mater Process Technol 138:152-155

163. Suzuki H, Moriwaki T, Yamamoto Y, Goto Y (2007) Precision cutting of aspherical ceramic molds with micro PCD milling tool. CIRP Ann Manuf Technol 56:131-134

164. Wang C, Gong YD, Yin GQ, Wen XL, Cheng J (2013) Study on micro mill-grinding technology. Appl Mech Mater 390:586-592

165. van der Zel JM Dental prosthesis and method for manufacturing a dental prosthesis, US Patent US5378154A, January 3rd 1995

166. Noiles DG Metallic prosthetic devices having micro-textured outer surfaces, US Patent US4865603, September 12th 1989

167. Schneider F, Bischof R, Kirsch B, Kuhn C, Müller R, Aurich JC (2016) Investigation of chip formation and surface integrity when micro-cutting cp-titanium with ultra-fine grain cemented carbide. Procedia CIRP 45:115-118

168. Herrera-Granados G, Morita N, Hidai H, Matsusaka S, Chiba A, Ashida K, Ogura I, Okazaki Y (2016) Development of a non-rigid micro-scale cutting mechanism applying a normal cutting force control system. Precis Eng 43:544-553

169. Kurniawan R, Kiswanto G, Ko TJ (2016) Micro-dimple pattern process and orthogonal cutting force analysis of elliptical vibration texturing. Int J Mach Tool Manu 106:127-140

170. Kim JH, Lee S-K (2016) Micro-patterning technique using a rotating cutting tool controlled by an electromagnetic actuator. Int $\mathrm{J}$ Mach Tool Manu 101:52-64

171. Zhang J, Cui T, Ge C, Sui Y, Yang H (2016) Review of micro/nano machining by utilizing elliptical vibration cutting. Int J Mach Tool Manu 106:109-126

172. Herrera-Granados G, Morita N, Hidai H, Matsusaka S, Chiba A, Ashida K, Ogura I, Okazaki Y (2015) Experimental stress analysis of glass cutting using a non-rigid cutting mechanism. Manuf Lett 6:14-18

173. Zhang L, Xie J, Guo RB, Wu KK, Li P, Zheng JH (2016) Precision and mirror micro-grinding of micro-lens array on macro-freeform glass substrate for micro-photovoltaic performances. Int J Adv Manuf Technol 86:87-96

174. Azami S, Kudo H, Mizumoto Y, Tanabe T, Yan J, Kakinuma Y (2015) Experimental study of crystal anisotropy based on ultraprecision cylindrical turning of single-crystal calcium fluoride. Precis Eng 40:172-181

175. Friedrich C, Coane P, Goettert J, Gopinathin N (1998) Direct fabrication of deep x-ray lithography masks by micromechanical milling. Precis Eng 22:164-173

176. Jaffery SHI, Khan M, Ali L, Mativenga PT (2016) Statistical analysis of process parameters in micromachining of Ti-6Al-4V alloy. Proc Inst Mech Eng B J Eng Manuf 230:1017-1034. https://doi. org/10.1177/0954405414564409

177. Jaffery SI, Driver N, Mativenga PT (2010) Analysis of process parameters in the micromachining of Ti-6Al-4V alloy. In: Hinduja $\mathrm{S}$, Li L (ed) Proceedings of the 36th International MATADOR Conference, Springer, London, pp. 239-242 